\title{
Prediction of blood-based biomarkers and subsequent design of bisulfite PCR-LDR- qPCR assay for breast cancer detection
}

\author{
Manny D. Bacolod ${ }^{1 *} \mathbb{D}$, Jianmin Huang ${ }^{1}$, Sarah F. Giardina', Philip B. Feinberg ${ }^{1}$, Aashiq H. Mirza', Alexander Swistel², \\ Steven A. Soper ${ }^{3}$ and Francis Barany ${ }^{1 *}$
}

\begin{abstract}
Background: Interrogation of site-specific CpG methylation in circulating tumor DNAs (ctDNAs) has been employed in a number of studies for early detection of breast cancer (BrCa). In many of these studies, the markers were identified based on known biology of BrCa progression, and interrogated using methyl-specific PCR (MSP), a technique involving bisulfite conversion, PCR, and qPCR.
\end{abstract}

Methods: In this report, we are demonstrating the development of a novel assay (Multiplex Bisulfite PCR-LDR-qPCR) which can potentially offer improvements to MSP, by integrating additional steps such as ligase detection reaction (LDR), methylated CpG target enrichment, carryover protection (use of uracil DNA glycosylase), and minimization of primer-dimer formation (use of ribose primers and RNAseH2). The assay is designed to for breast cancer-specific CpG markers identified through integrated analyses of publicly available genome-wide methylation datasets for 31 types of primary tumors (including $\mathrm{BrCa}$ ), as well as matching normal tissues, and peripheral blood.

Results: Our results indicate that the PCR-LDR-qPCR assay is capable of detecting $\sim 30$ methylated copies of each of 3 BrCa-specific CpG markers, when mixed with excess amount unmethylated CpG markers ( 3000 copies each), which is a reasonable approximation of BrCa ctDNA overwhelmed with peripheral blood cell-free DNA (cfDNA) when isolated from patient plasma. The bioinformatically-identified $\mathrm{CpG}$ markers are located in promoter regions of NR5A2 and PRKCB, and a non-coding region of chromosome 1 (upstream of EFNA3). Additional bioinformatic analyses would reveal that these methylation markers are independent of patient race and age, and positively associated with signaling pathways associated with BrCa progression (such as those related to retinoid nuclear receptor, PTEN, p53, pRB, and p27).

Conclusion: This report demonstrates the potential utilization of bisulfite PCR-LDR-qPCR assay, along with bioinformatically-driven biomarker discovery, in blood-based BrCa detection.

Keywords: Breast cancer, Methylation, Early detection, Ligase detection reaction, Biomarker

\section{Background}

In 2019, the projected number of new cases of and deaths due to breast cancer $(\mathrm{BrCa})$ in the United States, are 271,270 , and 42,260 respectively [1]. Worldwide, the corresponding numbers (2018 estimate) are 2,088,849, and 626,679 respectively [2]. It is the second-leading cause of cancer death in women, one in 8 of whom will

\footnotetext{
*Correspondence: mdb2005@med.cornell.edu; barany@med.cornell.edu ${ }^{1}$ Department of Microbiology and Immunology, Weill Cornell Medicine, New York, NY 10065, USA

Full list of author information is available at the end of the article
}

acquire the disease in her lifetime. Although genetic predisposition (i.e. BRCA1/2 mutations) is an important contributing factor $(5-10 \%)[3,4]$, most $\mathrm{BrCa}$ cases are those without clear genetic link (it may still be due to unknown genetic risk, thus considered familial). While Stage I cases have close to 100\% 5-year survival rate, those diagnosed at Stage IV have a 5-year relative survival rate of only $22 \%$, accounting for $6-10 \%$ of new $\mathrm{BrCa}$ cases and $20-30 \%$ all of recurrent disease [5]. The early detection of $\mathrm{BrCa}$ saves lives and reduces the morbidity associated with the aggressive treatments required

(c) The Author(s). 2020 Open Access This article is distributed under the terms of the Creative Commons Attribution 4.0 International License (http://creativecommons.org/licenses/by/4.0/), which permits unrestricted use, distribution, and reproduction in any medium, provided you give appropriate credit to the original author(s) and the source, provide a link to the Creative Commons license, and indicate if changes were made. The Creative Commons Public Domain Dedication waiver (http://creativecommons.org/publicdomain/zero/1.0/) applies to the data made available in this article, unless otherwise stated. 
for treating late-stage cancers. Nevertheless, the primary diagnostic screening method, mammography, has high rates of false positive and false negatives, can result in over-diagnosis, uses harmful radiation, and is an uncomfortable process for patients [6,7]. This necessitates the pursuit of molecular markers more indicative of a tumor's biological characteristics translatable to a reliable, non-invasive diagnostic assay. Over the years, there have been numerous reports indicating that either blood serum, plasma, or whole blood can harbor molecular biomarkers indicative of a progressing $\mathrm{BrCa}[3,8,9]$. These markers include: secreted proteins (e.g. CA15-3, trefoil factors 1, 2, and 3), auto-antibodies (e.g. antibodies against human endogenous retrovirus-K(HML-2) and heterogeneous nuclear ribonucleoprotein F), lipids (e.g. C16:1, C18:3, C18:2), and microRNAs (e.g. miR-21, miR-221, miR-145). In addition to the blood-based markers mentioned above, there is growing field exploring the use of DNA fragments released by cancer cells (referred to as circulating tumor DNAs or ctDNAs) into the patient's bloodstream as an indicator of cancer [10, 11]. Previous studies proved that genomic signatures (e.g. mutation, copy number variation, $\mathrm{CpG}$ methylation) found in cancer tissues are largely concordant with those identified in ctDNAs [12-18]. Already marketed are early cancer diagnostic tests based on interrogating sitespecific CpG hypermethylation in ctDNAs isolated from patient plasma. These include: a) Epi proColon, ColoVantage, Realtime $\mathrm{mS9}$, all of which detect methylation in the SEPT9 gene for colon cancer detection [19]; b) Epi proLung which detects methylation of $\mathrm{SHOX} 2$ for lung cancer detection [20], and c) Colvera, which detects methylation at BCAT1 and IKZF1 for colon cancer recurrence [21].

There are important considerations in the development of methylation-based early detection assays for $\mathrm{BrCa}$ (or any other cancer type). Although the levels of plasma-derived cell free DNA (cfDNA) in serum from cancer patients are indeed abnormally high in early- to late-stage cancers [22-24], only a small percentage are ctDNAs (most cfDNAs are hematological in origin). Another important concern is the selection of appropriate markers. At the very least, the selected CpG sites should be highly methylated in breast primary tumors (PTs) and practically unmethylated in peripheral blood. However, for a marker to be highly specific to $\mathrm{BrCa}$ PTs, it needs to have very low levels of methylation in normal breast tissues, and many other tumor types. In this report, we demonstrate a new and more sensitive assay for methylated CpG detection (incorporating various steps including ligase detection reaction), and a comprehensive approach to biomarker discovery using integrated public genomic datasets.

\section{Methods}

\section{Public genomic datasets}

Analyzed for this study are various publicly available genomic datasets (Additional file 1: Supplement 1) such as those released by the TCGA project (https://www. cancer.gov/about-nci/organization/ccg/research/structural-genomics/tcga) [25] and those deposited in the Gene Expression Omnibus (https://www.ncbi.nlm.nih. gov/geo/). The primarily Illumina $450 \mathrm{~K}$ methylation array-generated TCGA datasets were previously compiled (and processed) in the UCSC Cancer Genomics website (https://genome-cancer.ucsc.edu/) [26, 27]. The TCGA cohorts included in our analyses are: breast invasive carcinoma [BRCA], adrenocortical carcinoma [ACC], bladder urothelial carcinoma [BLCA], cervical squamous cell carcinoma and endocervical adenocarcinoma [CESC], cholangiocarcinoma [CHOL], colon adenocarcinoma [COAD], lymphoid neoplasm diffuse large bcell lymphoma [DLBC], esophageal carcinoma [ESCA], glioblastoma multiforme [GBM], head and neck squamous cell carcinoma [HNSC], kidney chromophobe carcinoma $[\mathrm{KICH}]$, kidney renal clear cell carcinoma [KIRC], kidney renal papillary cell carcinoma [KIRP], brain lower grade glioma [LGG], liver hepatocellular carcinoma [LIHC], lung adenocarcinoma [LUAD], lung squamous cell carcinoma [LUSC], mesothelioma [MESO], pancreatic adenocarcinoma [PAAD], pheochromocytoma and paraganglioma [PCPG], prostate adenocarcinoma [PRAD], rectum adenocarcinoma [READ], sarcoma [SARC], skin cutaneous melanoma [SKCM], stomach adenocarcinoma [STAD], testicular germ cell tumors [TGCT], thymoma [THYM], thyroid carcinoma [THCA], uterine corpus endometrial carcinoma [UCEC], uterine carcinosarcoma [UCS], and uveal melanoma [UVM]. Also crucial to our biomarker identification is the integration of various GEO datasets such as: GSE65820 (ovarian cancer PTs and matching normals) [28], GSE46306 (normal tissues of the cervix) [29], GSE99553 (gastric mucosa), GSE74104 (testis) [30], GSE77871 (adrenal tissues), GSE51954 (dermis and epidermis) [31], GSE64509 (various brain tissues) [32], GSE42861 (peripheral blood) [33], and GSE59250 (various immune cells from healthy individuals) [34]. The methylation data for $\mathrm{BrCa}$ cell lines were extracted from the GEO datasets GSE57342 [35], GSE68379 [36], GSE78875 [37], and GSE94943.

\section{Bioinformatic and statistical analyses}

Programs and other tools All statistical analyses (comparative statistics, normalization, correlation and regression analyses, multivariate analyses, hierarchical clustering) were performed using JMP Pro 11/ JMP Genomics software (SAS, Cary, NC), and Gene-E (Broad 
Institute, Cambridge, MA). Genomic sequence extraction and alignment were performed through the UCSC Genome Browser (https://genome.ucsc.edu/) [38]. The OligoAnalyzer Tool from IDT (https://www.idtdna.com/ pages/tools/oligoanalyzer) aided in our primer designs.

Prediction of blood-based, breast cancer-specific methylation markers The primary task was to identify CpG markers whose high degree of methylation in blood cfDNA may be indicative of primary $\mathrm{BrCa}$, but (as much as possible) not of normal breast cells, peripheral blood, and many other cancer types. There are multiple approaches which can be employed to accomplish this task. Our approach started with simplifying each subgroup (e.g. PTs, solid normals) of a given cohort (e.g. TCGA-BRCA, TCGA-COADREAD), into arbitrarily defined metrics. In this case, the CpG marker $\mathbf{P}$ for a given cohort $\mathbf{C}$, and cohort subset $\mathbf{S}$ was associated with specific statistical value $\mathbf{V}$, such as \%UM, \%IM, \%LM, $\% \mathrm{HM}, \% \mathrm{UM}+\% \mathrm{IM}$, and $\% \mathrm{LM}+\% \mathrm{HM}$, wherein $\mathrm{UM}$, IM, $\mathbf{L M}, \mathbf{H M}$ respectively refer to UnMethylated $\left(\beta_{\mathrm{P}} \leq\right.$ $0.15 ; \beta=$ fraction of methylation at marker $\mathbf{P})$, Indeterminately Methylated $\left(0.15<\beta_{\mathrm{P}} \leq 0.3\right)$, Lowly Methylated $\left(0.3<\beta_{P} \leq 0.6\right)$, and Highly Methylated $\left(\beta_{P}>0.6\right)$ at the marker $\mathbf{P}$. The candidate markers (P's) were dynamically identified by isolating $\mathrm{CpG}$ sites which satisfied multiple criteria in the general form: $\mathbf{V}_{\mathbf{P}(\mathbf{C}, \mathbf{S})} \geq \mathrm{n} ;\{0 \leq n \leq 100\}$.

Assessment of methylation markers' relationship with various clinico-pathological data The accompanying clinico-pathological (such as pathological stage, PAM50 molecular subtype, age, race, and ethnicity) were used to assess their influence in the $\mathrm{CpG}$ markers' $\beta$ values.

Assessment of methylation markers' roles in epigenetic regulation and other functionalities The genome-wide transcriptional data (RNASeq-generated) for the BRCA cohort was also integrated into the analyses. First, the combined transcriptional and methylation data enabled us to predict if the CpG sites can potentially influence the transcription of their respective genes. Second, Gene Set Enrichment Analysis [39] was employed to predict the genes or pathways (http://software.broadinstitute.org/gsea/msigdb/genesets.jsp) that tend to be enriched (or upregulated) when a particular CpG site is highly methylated (such as some of the CpG sites which will eventually be verified experimentally).

\section{Cell lines and genomic DNAs}

The BrCa cell lines SKBr3, MDA-MB-134VI, and MCF7, which would serve as sources of cancer genomic DNAs (gDNAs), were grown according to culture conditions recommended by ATCC (https://www.atcc.org/). At 8090\% confluence, the cells were washed with Phosphate
Buffered Saline $(\times 3)$, and collected by centrifugation $(500 \mathrm{x}$ g). gDNAs were isolated using the DNeasy Blood \& Tissue Kit (Qiagen; Valencia, CA). gDNA (>50 kb size) isolated from blood (buffy coat) of healthy individuals was purchased from Roche (Indianapolis, IN) (also referred to as "Roche DNA"). Quant-iT Picogreen Assay (Life Technologies/Thermo Fisher; Waltham, MA) was used to determine gDNA concentration. The isolated gDNAs were then fragmented (50 bp to $1 \mathrm{~kb}$ size) using an ultra-sonicator from Covaris (Woburn, Massachusetts). The fragmentation size was assessed using the Agilent Bioanalyzer System.

\section{Enrichment of methylated genomic DNA}

The gDNA fragments containing CpG methylated fragments were enriched using the EpiMark ${ }^{\circ}$ Methylated DNA Enrichment Kit (New England BioLabs, Ipswich, MA). This approach uses selective binding of doublestranded methyl-CpG DNA to the methyl-CpG binding domain of human MBD2 protein fused to the Fc tail of human IgG1. The fused IgG1 (MBD2-Fc) antibody is coupled to paramagnetic hydrophilic protein A magnetic beads. The enrichment procedure was carried out according to the manufacturer's instructions.

\section{Bisulfite conversion of digested genomic DNA}

Bisulfite conversion of cytosine bases was accomplished using the EZ DNA Methylation-Lightning kit from Zymo Research Corporation (Irvine, CA). In brief, $130 \mu \mathrm{l}$ of Lightning Conversion Reagent was added to $20 \mu \mathrm{l}$ of previously enriched gDNA fragments. Subsequent protocol steps (according to the manufacturer's instructions) led to elution of bisulfite converted DNA fragments in $10 \mu \mathrm{l}$ of elution buffer.

\section{PCR-LDR-qPCR}

The assay we developed for detection of plasma-based $\mathrm{BrCa}$ methylation markers is divided into several steps described in following subsections. All primers (Additional file 1: Supplement 2) were purchased from Integrated DNA Technologies Inc. (Coralville, IA).

\section{Linear amplification}

In a $25 \mu \mathrm{l}$ of reaction volume, the linear amplification step was carried out by mixing: $5.0 \mu \mathrm{l}$ of corresponding bisulfite converted DNA template (out of $50 \mu \mathrm{l}$ of eluted DNA after bisulfite conversion), $5 \mu$ l of $5 x$ GoTaq Flexi buffer (no Magnesium) (Promega, Madison, WI), $2.5 \mu \mathrm{l}$ of $25 \mathrm{mM} \mathrm{MgCl}_{2}$ (Promega, Madison, WI), $0.5 \mu \mathrm{l}$ of 10 mM dNTPs (dATP, dCTP, dGTP and dTTP) (Promega, Madison, WI), $2.5 \mu \mathrm{l}$ of the reverse primer (or primers in case of multiplex reaction) $(1 \mu \mathrm{M}), 0.625 \mu \mathrm{l}$ of $20 \mathrm{mU} / \mu \mathrm{l}$ RNAseH2 (diluted in RNAseH2 dilution buffer from IDT) (IDT), and $0.55 \mu \mathrm{l}$ of KlenTaql polymerase (DNA 
Polymerase Technology, St. Louis, MO) mixed with Platinum Taq Antibody (Invitrogen/Thermo Fisher, Waltham, MA). The reactions were run in a ProFlex PCR system thermocycler (Applied Biosystems/ ThermoFisher, Waltham, MA) with the following program: 2 min at $94{ }^{\circ} \mathrm{C}, 40$ cycles of $\left(20 \mathrm{~s}\right.$ at $94{ }^{\circ} \mathrm{C}, 40 \mathrm{~s}$ at $60^{\circ} \mathrm{C}$, and $30 \mathrm{~s}$ at $72{ }^{\circ} \mathrm{C}$.), and a final hold at $4{ }^{\circ} \mathrm{C}$. After the reaction, Platinum Taq antibodies were added in the reaction mixture to inhibit the KlenTaq DNA polymerase. The KlenTaql/Platinum Taq Antibody mixture was prepared by adding $0.02 \mu \mathrm{l}$ of Klentaql polymerase at $50 \mathrm{U} /$ $\mu \mathrm{l}$ to $0.2 \mu \mathrm{l}$ of Platinum Taq Antibody at $5 \mathrm{U} / \mu \mathrm{l}$.

\section{$P C R$}

For the PCR reaction, $10 \mu \mathrm{l}$ of linear amplification product (previous step) was mixed with $2 \mu$ of $5 \mathrm{X}$ GoTaq Flexi buffer without Magnesium, $1 \mu \mathrm{l}$ of $25 \mathrm{mM} \mathrm{MgCl}_{2}$, $0.4 \mu \mathrm{l}$ of dNTPs $(10 \mathrm{mM}$ each of dATP, dCTP, dGTP and dUTP), $2 \mu \mathrm{l}$ of $0.5 \mu \mathrm{M}$ forward primer (or primers in case of multiplex reaction), $0.4 \mu \mathrm{l}$ of Antarctic Thermolabile UDG $(1 \mathrm{U} / \mu \mathrm{l})$ (New England Biolabs, Ipswich, MA), $0.25 \mu \mathrm{l}$ of $20 \mathrm{mU} / \mu \mathrm{l}$ RAseH2, $0.44 \mu \mathrm{l}$ of KlenTaql polymerase mixed with Platinum Taq Antibody (Invitrogen/Thermo Fisher, Waltham, MA). The KlenTaql / Platinum Taq Antibody mixture was prepared by adding $0.02 \mu \mathrm{l}$ of $50 \mathrm{U} / \mu \mathrm{l} \mathrm{Klentaql}$ polymerase to $0.2 \mu \mathrm{l}$ of $5 \mathrm{U} / \mu \mathrm{l}$ Platinum Taq Antibody. The $20 \mu \mathrm{l}$-volume reactions were run in a ProFlex PCR system thermocycler, using the following program: $10 \mathrm{~min}$ at $37^{\circ} \mathrm{C}, 40$ cycles of $(20 \mathrm{~s}$ at $94^{\circ} \mathrm{C}, 40 \mathrm{~s}$ at $60^{\circ} \mathrm{C}$. and $30 \mathrm{~s}$ at $\left.72^{\circ} \mathrm{C}\right), 10 \mathrm{~min}$ at $99.5^{\circ} \mathrm{C}$, and a final hold at $4{ }^{\circ} \mathrm{C}$.

\section{LDR}

The LDR step was performed in a $20 \mu \mathrm{l}$ reaction prepared by combining: $5.82 \mu \mathrm{l}$ of nuclease-free water (IDT), $2 \mu \mathrm{l}$ of 10X AK16D ligase reaction buffer $0.5 \mu \mathrm{l}$ of $40 \mathrm{mM}$ DTT (Sigma-Aldrich, St. Louis, MO), $0.25 \mu \mathrm{l}$ of $40 \mathrm{mM}$ NAD+ (Sigma-Aldrich, St. Louis, MO), $0.5 \mu \mathrm{l}$ of $20 \mathrm{mU} / \mu \mathrm{l}$ RNAseH2, $0.4 \mu \mathrm{l}$ of $500 \mathrm{nM}$ LDR upstream probes, $0.4 \mu \mathrm{l}$ of $500 \mathrm{nM}$ LDR downstream probes, $0.57 \mu \mathrm{l}$ of purified AK16D ligase (at $0.88 \mu \mathrm{M}$ ), and $4 \mu \mathrm{l}$ of PCR reaction products from previous step. The AK16D ligase reaction buffer (at $1 \mathrm{X}$ ) contains the following: 20 $\mathrm{mM}$ Tris-HCI at $\mathrm{pH} 8.5,5 \mathrm{mM} \mathrm{MgCl}_{2}, 50 \mathrm{mM} \mathrm{KCl}, 10$ $\mathrm{mM}$ DTT, and $20 \mu \mathrm{g} / \mathrm{ml}$ of BSA (all components purchased from Sigma Aldrich, St. Louis, MO). LDR reactions were run in a ProFlex PCR system thermocycler using the following program: 20 cycles of $\left(10 \mathrm{~s}\right.$ at $94^{\circ} \mathrm{C}$, and $4 \mathrm{~min}$ at $60^{\circ} \mathrm{C}$ ) followed by a final hold at $4{ }^{\circ} \mathrm{C}$.

\section{Taqman real-time $q P C R$}

The qPCR reaction was performed in a $10 \mu \mathrm{l}$ of reaction mixture prepared by mixing: $1.5 \mu \mathrm{l}$ of nuclease-free water (IDT), $5 \mu \mathrm{l}$ of $2 \mathrm{X} \mathrm{TaqMan}^{\circ}$ Fast Universal PCR
Master Mix (Fast AmpliTaq, UDG and dUTP)(Applied Biosystems/ThermoFisher; Waltham, MA), $1 \mu \mathrm{l} 2.5 \mu \mathrm{M}$ forward primer at, $1 \mu \mathrm{l}$ of $2.5 \mu \mathrm{M}$ reverse primer, $0.5 \mu \mathrm{l}$ of $5 \mu \mathrm{M}$ probe, and $1 \mu \mathrm{l}$ of LDR reaction products from the previous step. All qPCR reactions were run in a ViiA7 real-time thermo-cycler from Applied Biosystems (Applied Biosystems/ThermoFisher; Waltham, MA), using MicroAmp ${ }^{\circ}$ Fast-96-Well Reaction $0.1 \mathrm{ml}$ plates sealed with MicroAmp ${ }^{\text {mi }}$ Optical adhesive film (Applied Biosystems/ThermoFisher; Waltham, MA). The run settings were as follows: fast block, Standard curve as experiment type, ROX as passive reference, TAMRA as reporter, and NFQ-MGB as quencher; program at $2 \mathrm{~min}$ at $50{ }^{\circ} \mathrm{C}$, and 40 cycles of $\left(1 \mathrm{~s}\right.$ at $95^{\circ} \mathrm{C}$, and $20 \mathrm{~s}$ at $\left.60^{\circ} \mathrm{C}\right)$.

\section{Taqman digital $q P C R$}

For each digital PCR reaction, a $20 \mu \mathrm{l}$ mixture was prepared in each of the 96 well digital PCR microplate. The mixture included $2 \mu \mathrm{l}$ of diluted LDR product (Step 3), $1 \mathrm{X}$ Luna Universal ProbeqPCR master mixture, 0.1\% tween 20, $0.4 \mathrm{mU}$ RNAseH2, $0.025 \mathrm{U}$ Antarctic Thermolabile UDG, $5 \mu \mathrm{M}$ each of forward and reverse primers, and Taqman probe. $12 \mu \mathrm{l}$ of reaction mixture was loaded into the Constellation Digital PCR System (originally Formulatrix, Bedford, MA; currently Qiagen), and run with the following conditions: $37^{\circ} \mathrm{C}$ for $10 \mathrm{~min}, 95^{\circ} \mathrm{C}$ for $20 \mathrm{~s}$, and 45 cycles of $5 \mathrm{~s}\left(94^{\circ} \mathrm{C}\right)$, and $20 \mathrm{~s}\left(60^{\circ} \mathrm{C}\right)$.

\section{Results}

\section{Identification of potential blood-based breast cancer} (BrCa) methylation markers

The BrCa methylation markers were identified (See Fig. 1) by applying the following filters: a) $\% \mathrm{HM}_{(\mathrm{BRCA}, \mathrm{PT})} \geq 30$; $\left.\mathbf{b}\right)$ $\left.\% \mathrm{UM}_{(\mathrm{BRCA}, \mathrm{SN})} \geq 40 ; \mathbf{c}\right)$ Average $(\% \mathrm{UM}){ }_{(\mathrm{C}, \mathrm{S})} \geq 40 ; \mathrm{C}=$ any cancer cohort $\neq$ BRCA, $\mathrm{S}=\mathrm{PTs}$, d) Ave. $(\% \mathrm{UM})_{(\mathrm{C}, \mathrm{S})} \geq 40$; $\mathrm{C}=$ any cancer cohort $\neq \mathrm{BRCA} ; \mathrm{S}=$ Solid normals; and e) \% UM (GSE42861,blood) $\geq 98$. A total of 229 CpG sites passed these filters. Among these are located in the loci of CPXM1, RASSF1A, and SC3BGA1, which have been reported in the literature to be indicative of $\mathrm{BrCa}$ [3]. Selected for further studies are the CpG sites located in the promoter regions of NR5A2 (nuclear receptor subfamily 5 group A member) (referred to as " $\mathrm{m} \_\mathrm{NR} 5 \mathrm{~A} 2$ ) and PRKCB (protein kinase $C$ beta) $\left(\mathrm{m} \_\mathrm{PRKCB}\right)$, as well as a CpG site in a non-coding region of chromosome 1 (m_ncr1) (Additional file 1: Supplement 3). The 3 aforementioned CpG sites were selected after further statistical inspections (i.e. the ones most likely to differentiate $\mathrm{BrCa}$ with other major cancer types), and assessment of surrounding sequences (i.e. to make sure assay can be designed around the target $\mathrm{CpG}$ sites). Of the 3 markers, m_ncr1 appears to be most highly specific to BrCa PTs (Fig. 2, Additional file 1: Supplement 4). The average methylation $(\bar{\beta})$ of $m \_n c r 1$, among BRCA PTs is 


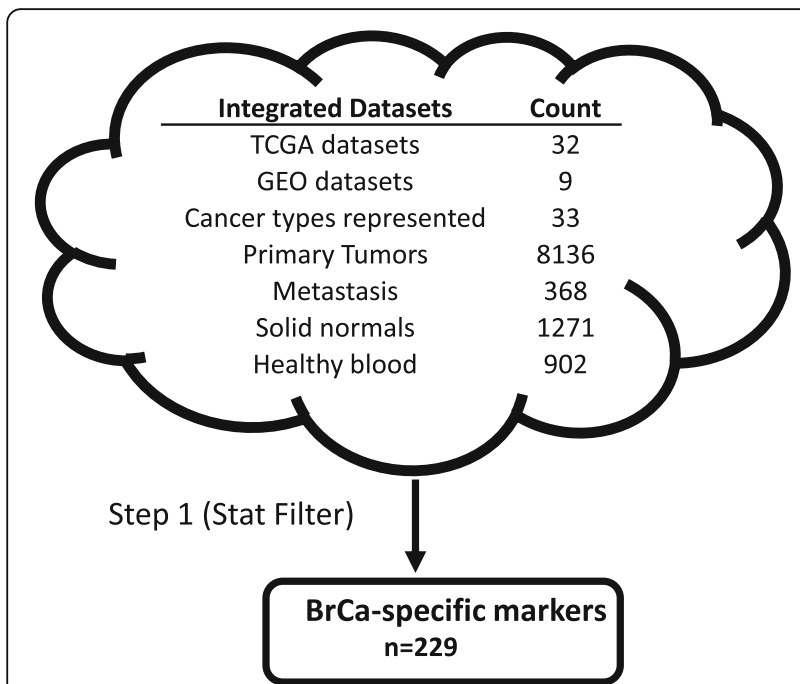

Step 2 (Additional inspections)

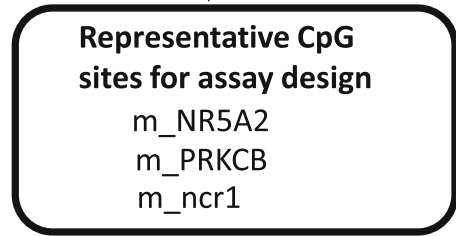

Fig. 1 The scheme employed to identify potential site-specific methylation markers for blood-based early detection of breast cancer

0.536 (on the scale 0 to 1 , with 1 being $100 \%$ methylated). For other major cancer types such as ovarian cancer $(\mathrm{OV})$, endometrial cancer (UCEC), colorectal cancer (COADREAD), lung adenocarcinoma (LUAD), lung squamous cell carcinoma (LUSC), and pancreatic cancer (PAAD), the $\bar{\beta}$ values for PTs (or $\bar{\beta}$ PT) range from 0.030 to 0.093 . In contrast, the $\bar{\beta}$ for normal tissues (or $\bar{\beta}$ SN) is 0.206 for normal breast, and ranged from 0.028 to 0.066 in other tissue types. As shown in Fig. 2 and Additional file 1: Supplement 4, $\mathrm{m}_{-}$ NR5A2 is very highly methylated in BRCA PTs $\left(\bar{\beta}{ }_{\mathrm{PT}}=\right.$ 0.604). However, it also exhibits a high level of methylation in lung cancer $\left(\bar{\beta}_{\text {PT }}\right.$ equals 0.454 and 0.436 for LUAD and LUSC PTs respectively). Among the major cancer types, the marker $\mathrm{m}_{-} \mathrm{PRKCB}$ exhibits the highest degree of methylation $\left(\bar{\beta}_{\mathrm{PT}}\right.$ equals 0.561$)$. Nonetheless, this particular marker may also test positive for $\operatorname{LUAD}(\bar{\beta}$ PT $=0.446)$, $\operatorname{PAAD}\left(\bar{\beta}_{\mathrm{PT}}=0.498\right), \operatorname{UCEC}\left(\bar{\beta}_{\mathrm{PT}}=0.328\right)$, and COAD$\operatorname{READ}\left(\bar{\beta}_{\mathrm{PT}}=0.362\right)$.

\section{Relationship of select CpG markers with other clinicopathological profiles}

It is also possible to examine the various clinicopathological information which may be associated with the methylation markers' $\beta$ values. As expected, more progressive tumors tend to have higher $\bar{\beta}$ PT values. For example, the m_ncr1 $\bar{\beta}$ PT values for Stage I, II, and III are $0.499,0.534$, and 0.590 respectively (Additional file 1: Supplement 5). For m_NR5A2, these respective values are $0.552,0.610$, and 0.662 . For the $\mathrm{m}_{-} \mathrm{PRKCB}$ marker, while Stage III PTs registered the highest $\bar{\beta}$ PT $(0.611)$, the $\bar{\beta}$ Рт value for Stage I (0.562) is slightly higher than that of Stage II $(0.548)$. Nonetheless, the most statistically significant difference, across all markers, is between Stage I and Stage III PTs. Another noteworthy observation is that in all 3 markers, the Basal subtype registered the lowest $\bar{\beta}$ PT values. For example, the m_ncr1 $\bar{\beta}$ PT values for Basal, Luminal A (LumA), Luminal B (LumB), and HER2 tumors are 0.440, 0.532, 0.628, and 0.630 respectively (Additional file 1: Supplement 6). We did not find a substantial correlation $\left(\mathrm{R}^{2}\right.$ values range from 0.0 to 0.04 ) between patient age and methylation at each marker (irrespective of whether the tissue sample is a that of PT or solid normal) (See Additional file 1: Supplement 7). In addition, the methylation at each of the marker is independent of the racial (whether Asian, African American, or White) or ethnic (whether Hispanic or non-Hispanic) classification of the patient (Additional file 1: Supplements 8 and 9).

The predicted biological roles of $\mathrm{BrCa}$-specific methylation markers

The methylation level of either m_NR5A2 or m_PRKCB, apparently does not correlate with its transcript level (the respective $\mathrm{R}$ values are -0.198 and -0.123 ) (Additional file 1: Supplement 10). Nonetheless, it is still possible to bioinformatically demonstrate the association of these two CpG sites (along with m_ncr1, which is not part of the transcribed gene) with BrCa progression. It was accomplished in several ways. The first approach (See Fig. 3) was to identify the genes whose expression levels are most highly correlated with the methylation of the select markers. Indeed, a number of genes whose transcription positively and negatively correlated with each of the markers are known oncogenes and transcription factors respectively. For example, the expression of the transcription factor FOXA1, is highly (and positively) correlated with the methylation levels at $\mathrm{m}_{-} \mathrm{PRKCB}$ and m_NR5A2 (Fig. 3a and b). This transcription factor is needed for the transactivation of $\mathrm{p} 27^{\mathrm{Kip} 1}$ [40], which alone or in conjunction with BRCA1 may control gene expression pattern in luminal subtypes of $\mathrm{BrCa}$ [41]. Similarly, the expression of SPDEF has a high positive correlation with $\mathrm{m}_{-} \mathrm{PRKCB}$ and $\mathrm{m}_{-}$ncrl(Fig. $3 a$ and $\mathrm{c}$ ). Previous studies indicated that SPDEF (also a transcription factor) is upregulated in all al subtypes of $\mathrm{BrCa}$ (except basal), and is especially associated with $\mathrm{HR}$ 


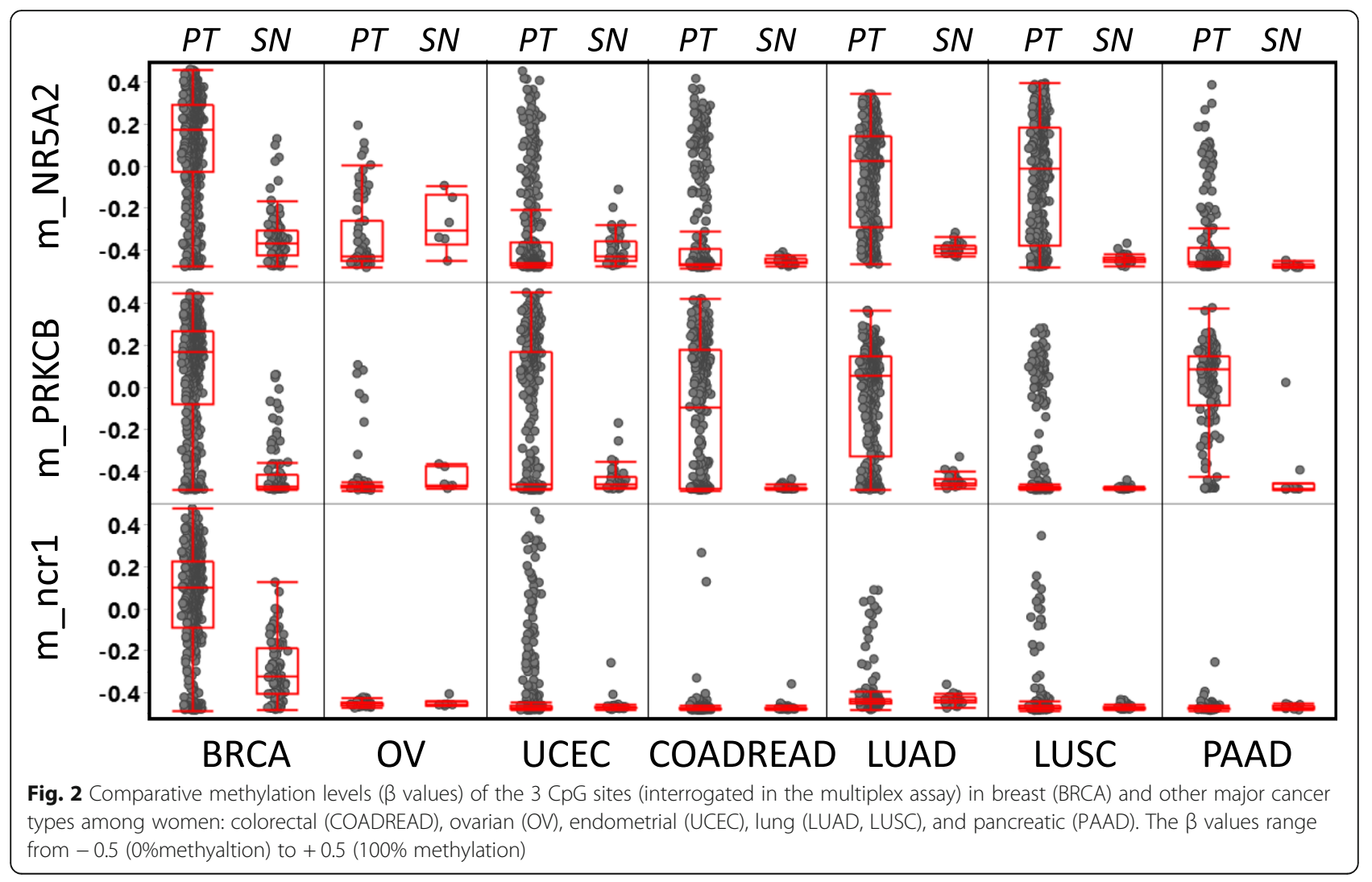

phenotype and nodal metastasis [42]. ERBB3 expression, which is positively correlated with methylation at $\mathrm{m}_{-}$ PRKCB and m_NR5A2 (Fig. 3a and b), can form a heterodimer with ERBB2, and subsequently activates downstream signaling leading to cell cycle progression [43]. Another transcription factor, GATA3 is positively correlated with both m_PRKCB and m_NR5A2 (Fig. 3a and b). Upregulated in all BrCA subtypes (except basal), GATA3 is associated with ER positive $\mathrm{BrCa}$ (shown to regulate the expression of ER gene itself) [44]. In contrast, many of the genes whose transcript levels are negatively correlated with the methylation at the $3 \mathrm{CpG}$ sites are known tumor suppressor genes. These include the genes CDC14B and SPRY2. CDC14B is a protein tyrosine phosphatase which can regulate RNA Pol II and repress cell cycle transcription [45]. SPRY2 acts as tumor suppressor in $\mathrm{BrCa}$ by inhibiting the Ras/Mitogen-Activated Protein Kinase Pathway [46], and in ovarian cancer, through inhibition of Amphiregulin (AREG)induced cell invasion [47].

Another approach to bioinformatically justify the potential of methylation markers in cancer detection is through genome-wide transcriptional comparison between two BrCa PT subsets: those highly methylated $(\mathbf{H})$, and those lowly methylated (L) at a particular CpG site p. The two subsets are defined as the follows: a) $\mathbf{H}$ subset includes PTs with $\beta_{\mathrm{p}}$ values higher by at least $1 \sigma$ from the mean $\left(\bar{\beta}_{\mathrm{p}}\right)$, and b) $\mathbf{L}$ subset includes BrCa PTs with $\beta_{p}$ values lower by at least $1 \sigma$ from the mean $\left(\bar{\beta}_{p}\right)$. Gene Set Enrichment Analysis (GSEA) [39] was then employed to identify the molecular pathways, as defined in Biocarta (https://www.gsea-msigdb.org/gsea/msigdb/ genesets.jsp?collection=CP:BIOCARTA) or Reactome (https://reactome.org/) [48] databases, most likely enriched in $\mathbf{H}$ over $\mathbf{L}$ subsets. Results from this analysis would indicate that gene sets associated with retinoid nuclear receptor signaling, are highly enriched in $\mathbf{H}$ over L subsets. These include: RARRXR (Nuclear receptors coordinate the activities of chromatin remodeling complexes and coactivators to facilitate initiation of transcription in carcinoma cells), VDR (Control of Gene Expression by Vitamin D Receptor), and CARM1 (Transcription Regulation by Methyltransferase of CARM1). In the RARRXR pathway, the binding of retinoids to RARA/RXRA nuclear receptor heterodimer initiates the transcriptional activation of cell proliferation-associated phosphatidylinositol 3-kinase (PI3K) [49]. Other studies point to RARRXR pathway's association with estrogen signaling [50, 51]. RARA/RXRA nuclear receptor plays a role in epigenetic regulation of Vitamin D Receptor (VDR). Previous studies have demonstrated VDR pathway's association with $\mathrm{BrCa}$ proliferation [52]. The 


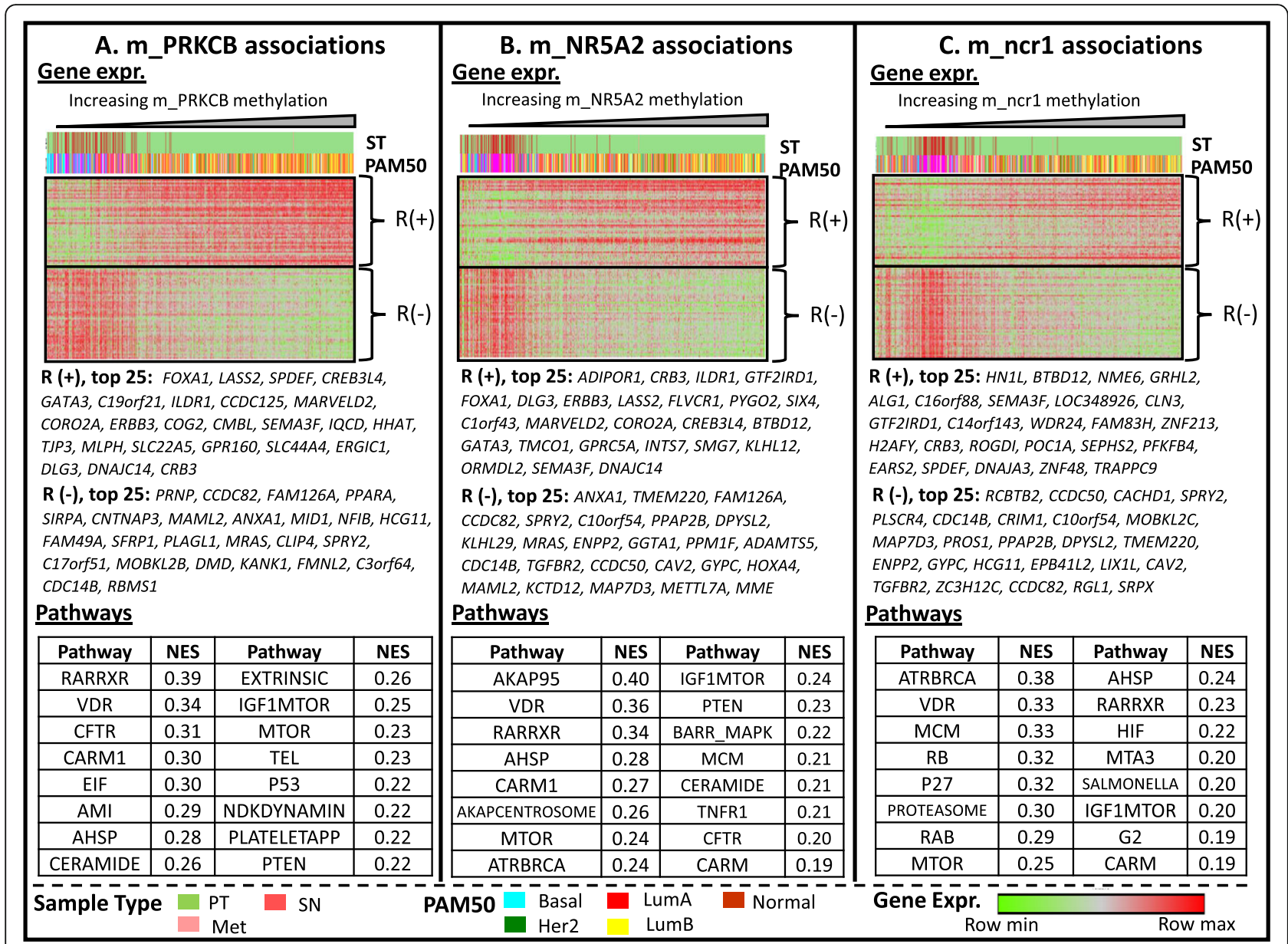

Fig. 3 Heatmaps depicting the genes whose transcript levels in breast cancer samples are most highly correlated (negative or positive) with the methylation at the 3 select CpG sites: a) m_PRKCB, b) m_NR5A2, c) m_ncr1

positive association between the methylation markers and CARM1 pathway is consistent with previous studies indicating that CARM1 (which codes for arginine methyltransferase) is involved in epigenetic transactivation of many nuclear receptors (NRs) including ER $\alpha$ [53]. CARM1 is also associated with poor prognosis in $\mathrm{BrCa}$ [54].

Also positively associated with at least one of the 3 methylation markers is the upregulation of cancer proliferation signaling pathways including: PTEN (PTEN dependent cell cycle arrest and apoptosis), P53 (p53 Signaling Pathway), P27 (Regulation of p27 Phosphorylation during Cell Cycle Progression), RB (RB Tumor Suppressor/Checkpoint Signaling in response to DNA damage), ATRBRCA (Role of BRCA1, BRCA2 and ATR in Cancer Susceptibility), and MTOR (mTOR Signaling Pathway). The enrichment of the aforementioned cancer pathways (in $\mathbf{H}$ over $\mathbf{L}$ PT subsets) may be explained by the upregulated expression of genes comprising these gene sets. These genes include: a) MAPK3, PDK2, and PTEN, of the PTEN gene set; b) BCL2, CCND1, RB1, TIMP3, and $M D M 2$ of the P53 gene set; c) E2F1 and CKS1B, of the
P27 gene set; d) CDC25C, MYT1, CDK1, and CD25B of the RB gene set; e) RAD51, BRCA1, FANCD2, and $B R C A 2$, of the ATRBRCA gene set; and f) EIF4EBP1 of the MTOR gene set.

\section{Multiplex bisulfite PCR-LDR-qPCR assay to validate the 3 breast cancer methylation markers}

In essence, the analyses described above rationalized that the methylation level at $3 \mathrm{CpG}$ sites (m_ncR1, mNR5A2, and $\mathrm{m}_{-} \mathrm{PRKCB}$ ) can serve as serum markers for progressing BrCa. With the aim of translating these findings to clinical use, we tested a homegrown procedure (bisulfite PCR-LDR-qPCR assay) (Fig. 4) designed to interrogate these methylated markers present in minuscule amount (i.e. down to less than 50 copies), as it is expected in cfDNA isolated from $\sim 10-\mathrm{ml}$ patient blood. The assay was tested on simulated cfDNA sample consisting of a mixture of gDNA fragments from $\mathrm{BrCa}$ cell line and peripheral blood from healthy patients, with the fragments from the latter present at $\sim 100$-fold relative to the former. It is a fair assumption that many of the $\mathrm{BrCa}$ cell 


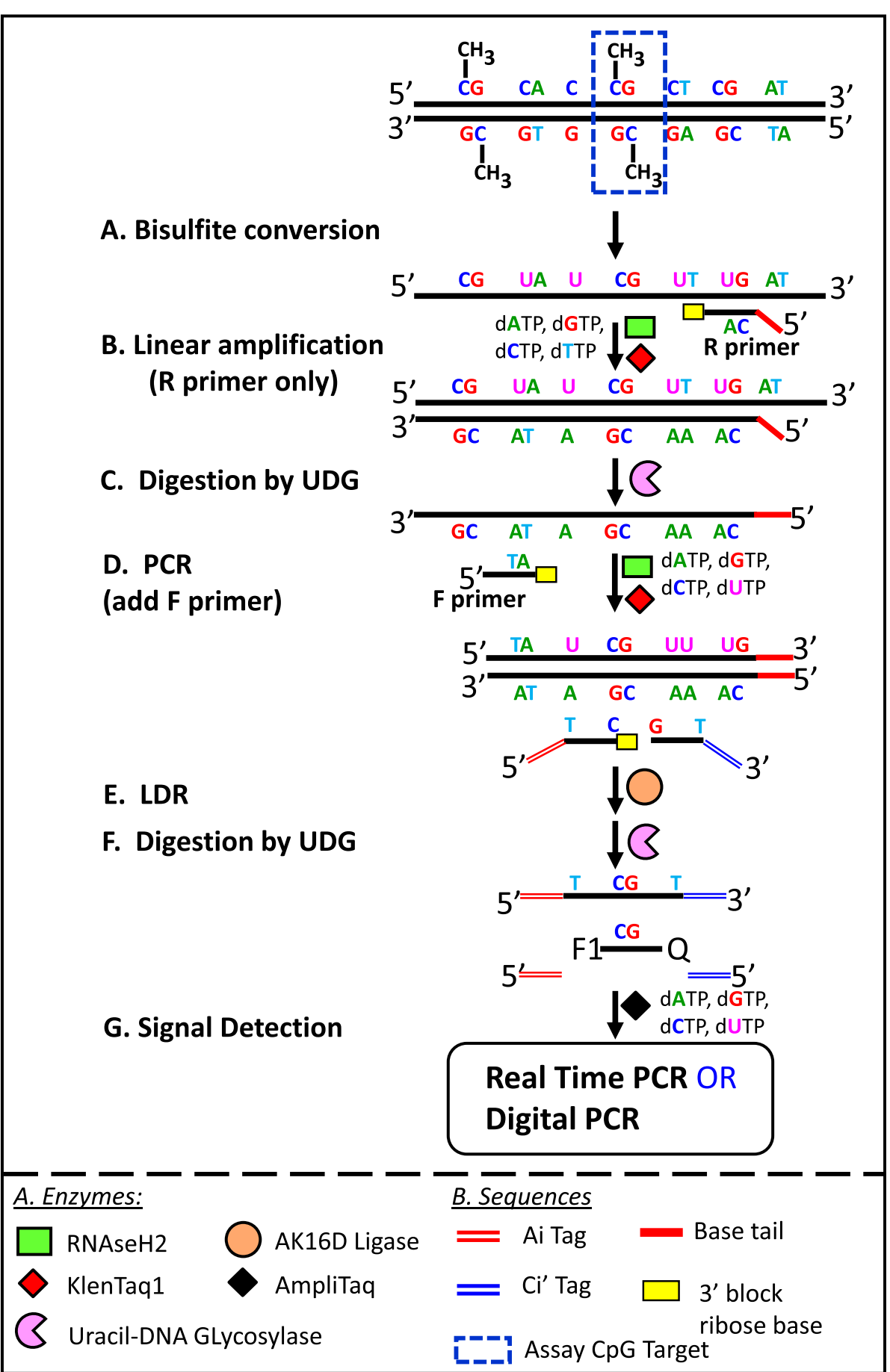

Fig. 4 Schematic of the Bisulfite PCR-LDR-qPCR assay for detection of CpG methylation

lines will be highly methylated at the $3 \mathrm{CpG}$ sites. Nonetheless, given the availability of genome-wide methylation datasets for many of the commonly used cancer cell lines, this assumption can easily be verified. According to the datasets GSE57342, GSE68379, GSE78875, and GSE94943, the average $\beta$ values for the CpG markers $\mathrm{m} \_$NR5A2, $\mathrm{m} \_$PRKCB, and $\mathrm{m} \_$ncr1 in the BrCa cell line
MCF7 are 0.96, 0.97, and 0.98 respectively (Fig. 5). For the cell line MDA-MB-134-VI, the respective numbers are $0.98,0.74$, and 0.99 . With this information, the gDNAs from these cell lines were isolated, fragmented, and enriched for methylation (through the use of fusion protein with the methyl-CpG binding domain, which can selectively bind DNA fragments containing 


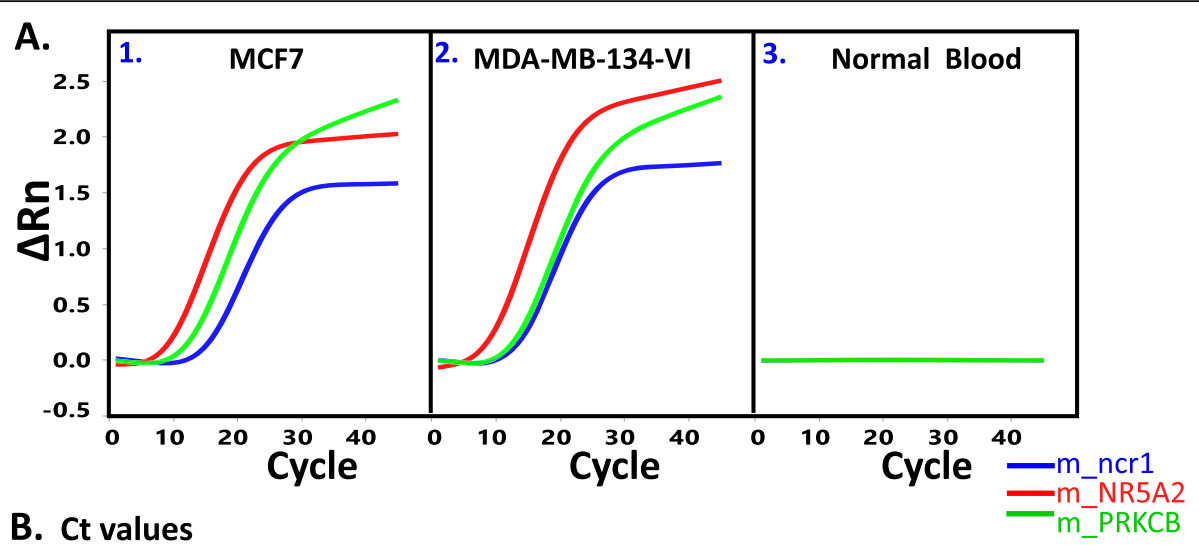

\begin{tabular}{|c|c|c|c|c|c|c|c|}
\hline $\begin{array}{c}\text { CpG } \\
\text { Site/Assay }\end{array}$ & MCF7 & $\begin{array}{c}\text { MDA-MB- } \\
134-V I\end{array}$ & $\begin{array}{c}\text { Normal } \\
\text { Blood }\end{array}$ & NTC (PCR 1) & NTC (PCR 2) & $\begin{array}{c}\text { NTC } \\
\text { (LDR) }\end{array}$ & NTC (qPCR) \\
\hline m_NR5A2 & 8.96 & 7.81 & No Ct & No Ct & No Ct & No Ct & No Ct \\
\hline m_PRKCB & 11.38 & 11.73 & No Ct & No Ct & No Ct & 40.01 & No Ct \\
\hline m_ncr1 & 14.75 & 12.70 & No Ct & No Ct & No Ct & No Ct & No Ct \\
\hline
\end{tabular}

\section{Beta values}

\begin{tabular}{|c|c|c|}
\hline CpG Site & MCF7 $^{*}$ & MDA-MB-134-VI** \\
\hline m_NR5A2 & 0.96 & 0.98 \\
\hline m_PRKCB & 0.97 & 0.74 \\
\hline m_ncr1 & 0.98 & 0.99 \\
\hline
\end{tabular}

Fig. 5 a. Panels 1 and $\mathbf{2}$ refer to the resulting Ct plots (from ViiA7 run) for multiplex detection of the CpG markers $m \_n c r 1, m \_N R 5 A 2$, and m_PRKCB using as initial template fragmented and bisulfite-converted mixture of 30, and 3000 genomic copies of DNA from breast cancer cell line (MCF7 or MDA-MB-134-VI) and normal human blood (Roche human genomic DNA) respectively. The DNA fragment mixture simulates the likely constitution of patient cfDNA (i.e. majority of which are released by peripheral blood cells). Panel $\mathbf{3}$ serves as a negative control (3000 copies of genomic DNA from normal human blood). $\mathbf{b}$. The Ct values for the plots depicted in $\mathbf{A}$. Also shown are results from no template controls (NTCs) in various steps of the assay (PCR, LDR, qPCR). "No Ct" means no amplification was detected after 45 cycles of real time PCR. c. The fraction of methylation at a specific CpG site for the $3 \mathrm{CpG}$ sites in the genomes of MCF7 and MDA-MB-134-VI cell lines, as extracted from Illumina $450 \mathrm{~K}$ array-generated datasets deposited in Gene Expression Omnibus (GEO). * Average values extracted from datasets GSE57342, GSE68379, GSE78875, and GSE94943. **Value extracted from dataset GSE68379

methylated CpG sites). As shown in the scheme (Fig. 4), the simulated cfDNA $(\sim 30$ and 3000 copies of cell line and peripheral DNA fragments respectively), was bisulfite-converted, then subjected to two-step PCR. The resulting amplicon would then serve as template for ligase detection reaction (LDR). The final step to detect the methylation signal was Taqman-based real time PCR, using the LDR products (from the previous step) as templates. The $C t$ values for $\mathrm{m}_{-}$NR5A2, $\mathrm{m}_{-} \mathrm{PRKCB}$, and $\mathrm{m}_{-}$ ncr1 were $8.96,11.38$, and 14.75 respectively for MCF7, and $7.81,11.73,12.70$ respectively for MDA-MB-134-VI. No $\mathrm{Ct}$ values registered for the unmixed peripheral blood for each of the marker. Indeed, the designed assays were capable of detecting minute amount of the $\mathrm{BrCa}$ methylation markers. These assays were designed to reduce false positive signals by minimizing nonspecific amplifications Among the important features are the $8-11$ base tails in the reverse PCR primers, meant to reduce the possibility of primer dimer formation. Also present were the ribose bases at the 3' end of the PCR and LDR primers. These sequences were removed by
RNaseH2 when the primers were bound to their targets, ensuring highly specific extension (for PCR) and ligation (for LDR). Carryover prevention was the objective of the timely addition of UDG, dUTP, or dTTP in the dNTP mixture [55]. Also, the tags in LDR primers ( $\left.\mathrm{Ai}, \mathrm{Ci}^{\prime}\right)$ allowed for uniformity (in terms of Tm) in qPCR reactions.

\section{Digital PCR as the final detection step}

Instead of Taqman PCR, digital PCR may also be used as detection step. For this experiment, we performed the 2-step PCR and LDR reactions as described above, using the primers for the detection of methylation at the CpG site located in the promoter region of the gene GRK7 (m_GRK7 or cg18768784; Chr3:_141516271-141,516, 272), although highly methylated in the $\mathrm{BrCa}$ cohort, has low BRCA-specificity. Nonetheless, there is a high degree of concordance between detection based in qPCR (Fig. 6a) and detection using the Constellation (Formulatrix) digital PCR System (Fig. 6b). The bisulfite converted DNA fragments consisting of $\sim 3000$ copies of unmethylated m_GRK7 (from peripheral blood) and 


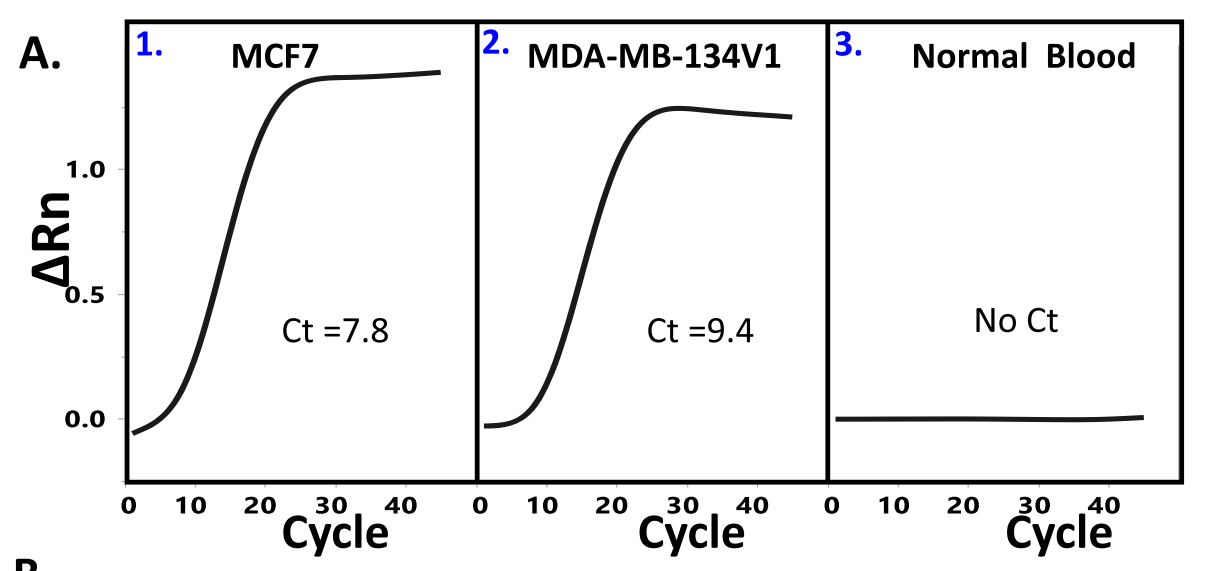

B.

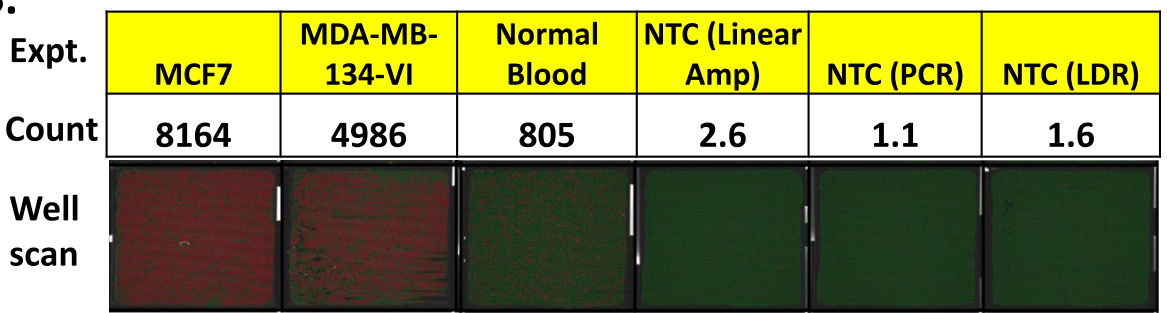

C.

Beta values

\begin{tabular}{|c|c|c|}
\hline & MCF7* & MDA-MB-134-VI** \\
\hline m_GRK7 & 0.88 & 0.72 \\
\hline
\end{tabular}

Fig. $\mathbf{6}$ a. Panels $\mathbf{1}$ and $\mathbf{2}$ refer to the resulting Ct plots (from ViiA7 run) for multiplex detection of the CpG marker m_GRK7, using as template 30 copies of bisulfite-converted and fragmented genomic DNA from breast cancer cell line (MCF7 or MDA-MB-134-VI) mixed with 3000 copies of genomic DNA from human blood (Roche human genomic DNA). Panel $\mathbf{3}$ refers to negative control, with just the normal blood genomic DNA as a template. b. A digital PCR readout (using Formulatrix Constellation dPCR System) for similar experiments depicted in A. NTC refers to "No template control". c. The fraction of methylation at a specific CpG site for m_GRK7 CpG site in the genomes of MCF7 and MDA-MB-134-VI cell lines. This information was extracted from Illumina $450 \mathrm{~K}$ array-generated datasets deposited in Gene Expression Omnibus (GEO). * Average value extracted from datasets GSE57342, GSE68379, GSE78875, and GSE94943. **Value extracted from dataset GSE68379

30 copies of methylated m_GRK7 yielded Ct values of 7.8 and 9.4 for MCF7 and MDA-MB-134VI respectively. The unmixed template (DNA fragments from peripheral blood only) did not register readable Ct. In the digital PCR detection system, the corresponding readings are 8164, 4986, and 805 for the MCF7, MDA-MB-134VI, and control (peripheral blood only) respectively.

\section{Discussion}

The limitations of mammography are what drives the persistent efforts towards developing non-invasive screening approaches for early $\mathrm{BrCa}$ detection. Falling under the term "liquid biopsy", many of the methods under investigation are technologies which aim to detect blood-based molecular markers originating from $\mathrm{BrCa}$ cells. The molecular markers can include cfDNA fragments, exosome-enclosed or naked RNA molecules, secreted proteins and metabolites $[8,9]$.

Of particular interest in the early-cancer detection field are circulating tumor DNAs (ctDNAs), which apoptotic and necrotic cancer cells release into patient plasma [56]. As expected, ctDNA fragments possess the same molecular signatures (somatic mutations, methylation, copy number variation/aberration, SNPs) present in gDNAs isolated from the tumor tissue samples. Hence, molecular characterization tools normally used to investigate cancer gDNAs (such as exome or genome-wide sequencing, PCR, DNA arrays, methylation arrays) have also been applied in ctDNA analysis [57]. What makes ctDNA analysis especially challenging is the fact that when isolated from patient plasma, ctDNAs are mixed with an overwhelming amount of DNA fragments that are hematopoietic in origin [58-60]. All of the fragments are collectively referred to as cell-free DNAs (or cfDNAs). According to a recent study, the ctDNAs originating from $\mathrm{BrCa}$ cells is just a small fraction of total cfDNAs [24]. This is based on the observation that the mutant allele fraction (MAF; from sequencing 58 cancer-related genes) of cfDNAs isolated from $\mathrm{BrCa}$ patients is less than $1 \%$ [24]. It is imperative that the assay 
employed to analyze cfDNAs is capable of distinguishing between the positive (several copies of ctDNAs) and mostly negative (from non-cancer cfDNAs) signals. This limitation of ctDNA analyses can be circumvented through the identification of more appropriate molecular biomarkers, along with the modification of assay biochemistry towards higher sensitivity and specificity. Although plasma-based ctDNA markers may include markers for mutations, methylation states, or copy number variations (most reports interrogate methylation and mutation markers), methylation markers have several inherent advantages. First, methylation changes are tissuespecific [61], thus as markers, would make them highly capable of distinguishing one cancer type from another. Another advantage of $\mathrm{CpG}$ methylation over mutation is that oftentimes the methylation changes adjacent $\mathrm{CpG}$ sites in promoter regions, are concordant. Methylationdependent procedures (such as the use of methyl DNAbinding antibodies) would then be more effective in enriching the fragments containing the highly methylated markers.

Identification of appropriate methylation markers (i.e. particular $\mathrm{CpG}$ sites) is very crucial. To pinpoint the specific $\mathrm{CpG}$ sites that can easily distinguish $\mathrm{BrCa}$ tissues from peripheral blood and other types of cancer, we took advantage of the availability of various genomewide methylation datasets. As previously pointed out, these calculations resulted in identification of 229 potential CpG markers which included CpG sites at the locus of RASSF1A (Ras association domain-containing protein $1)$, which happens to be the most highly reported bloodbased methylation markers for breast cancer [62-69]. Additional statistical inspections and assay design considerations would then point to the selection of the 3 CpG markers we focused on for this manuscript. Two of the CpG sites ( $\mathrm{m}_{-}$NR5A2 and $\left.\mathrm{m}_{-} \mathrm{PRKCB}\right)$ are located in promoter regions of genes, with reported link to breast cancer. NR5A2 (or LRH1) is a zinc finger transcription factor which can regulate CDKN1A expression in $\mathrm{BrCa}$ [70], and has been positively associated with BrCa proliferation [71], drug resistance [72], aggressiveness [73], high grade, and poor outcome [74]. On the other hand, the role of PRKCB in breast cancer progression is still not clearly defined. While there are reports indicating that PRKCB can promote mammary tumorigenesis [75], enhance breast cancer cells growth and cyclin D1expression [76], and has the potential as therapeutic target [77], there is also a report indicating it may inhibit tumor growth and metastasis [78]. The third CpG site interrogated by our assay (m_ncr1) is located less than $8000 \mathrm{bp}$ upstream of the exon 1 (according to GENCODE v31 annotation) of the protein coding gene EFNA3, a member of the ephrin (EPH) family. Whether this particular $\mathrm{CpG}$ site influences the expression of
EFNA3 protein, or the hypoxia-related EFNA3 lncRNA $[79,80]$ is not clear at this point.

Interestingly, the methylation level at m_NR5A2 and $\mathrm{m} \_$PRKCB did not correlate with the transcription of the corresponding genes (Additional file 1: Supplement 10). However, it is important to note that CpG methylation (at the promoter region) is not the only factor that influences gene transcription. It is quite possible that histone modification [81], regulatory miRNA or ncRNAs [82], as well as transcription factors can supersede CpG methylation in influencing transcription. The competition between mRNA transcription and mRNA degradation is a dynamic process that can determine the transcript level of a gene at any given time [83]. Regardless of $\mathrm{m}_{-}$ NR5A2 and m_PRKCB CpG sites' influence on their respective transcript levels, their association with $\mathrm{BrCa}$ progression is quite clear. This is further demonstrated through comparative genome-wide transcription analyses (which is essentially what GSEA is) of $\mathrm{BrCa}$ samples that are highly and lowly methylated at each CpG site. As shown in our analyses, the methylation level at each of the three methylation markers ( $\mathrm{m}_{-} \mathrm{ncr} 1, \mathrm{~m}_{-}$ NR5A2, and m_PRKCB), is positively associated with genes, processes, and pathways indicative of BrCa progression. These include processes (and much of the component genes) associated with the retinoid nuclear receptor, PTEN, p53, p27, RB, and MTOR signaling pathways.

A great majority of reports on the interrogation of $\mathrm{CpG}$ methylation in cfDNA for $\mathrm{BrCa}$ detection employed the methylation-specific PCR (MSP) approach. Aside from RASSF1, other genes whose CpG sites were observed to be hypermethylated in $\mathrm{BrCa}$ patient-derived cfDNAs (through MSP approach) are: $A K R 1 B 1, A R H-$ GEF7, BRCA1, BRMS1, COL6A2, CST6, CDKN2A, CCND2, DKK3, ESR1, GATA3, GPX7, GSTP1, HOXD13, HIST1H3C, HOXB4, ITIH5, KLK10, MSH2, MLH1, NBPF1, P16, PCDHGB7, RARB, RASGRF2, SOX17, SLIT2, SFN, SFRP1, SOX17, TM6SF1, TMEFF2, TRIM9, and WNT5A [84] [62, 64-69, 85-92]. The aforementioned CpG markers were selected because the genes have known roles in $\mathrm{BrCa}$ progression (primarily as tumor suppressors), or were previously identified from the use of earlier, much less dense version of Illumina methylation array (27 K).

Bisulfite conversion is perhaps the most crucial step in MSP. However, bisulfite conversion can cause the degradation of around $84-96 \%$ of the input cfDNA, and is thus a significant contributing factor to MSP's limitations in liquid biopsy [93]. This is not an issue in analyzing gDNAs extracted from tissues and cell lines, which the MSP assay was originally intended for. In some reports, $\mathrm{BrCa}$ patient cfDNAs were analyzed through methylated CpG digestion (e.g. BstUI enzyme), followed by $\mathrm{qPCR}$, with no bisulfite conversion step in the 
protocols [94-96]. However, results using this approach are not reliable (higher rates of false positives) if there is incomplete digestion of unmethylated CpG sites.

The assay we are proposing incorporated several features which can collectively improve the MSP approach. These include the following: a) selective enrichment of methylated DNA, through the methylated CpG capture by using methyl-DNA binding protein, b) signal amplification of the targeted CpG site through successive steps of bisulfite PCR and LDR, (c) prevention of non-specific primer extension by incorporating RNaseH2-targeted ribose bases at the 3' end of PCR and LDR primers, $\mathrm{d}$ ) prevention of carryover-contamination by PCR products originating from previous positive samples, through the use UDG enzyme, e) multiple primer binding regions for orthogonal amplification of a region containing the targeted CpG site, and f) multiplex format of the assays.

Bisulfite sequencing is capable of interrogating more CpG markers compared to site-specific bisulfite conversion assays [97-102]. However, we can only assume that the primary problems in MSP assays (the low abundance of cfDNAs and of target methylated CpG markers) are also encountered in bisulfite sequencing approaches. These factors, along with high cost, limits the recovery of information from bisulfite sequencing of cfDNA fragments [103].

\section{Conclusion}

This report demonstrates the steps which can be utilized to improve blood-based early detection assays for $\mathrm{BrCa}$ detection, including bioinformatic identification and characterization of the biomarkers and improvements in assay biochemistry. Understandably, the assays were only tested on simulated cfDNA samples. However, in future studies, we will evaluate the non-invasive $\mathrm{BrCa}$ diagnostic capability of our multiplex PCR-LDR-qPCR assay through analysis of patient-derived cfDNAs.

\section{Supplementary information}

Supplementary information accompanies this paper at https://doi.org/10. 1186/s12885-020-6574-4.

Additional file 1: Supplement 1. The cohorts analyzed for biomarker discovery. Legends: PT (primary tumors), SN (solid normal), PB (peripheral blood), Met (metastasis), Imm (immune cells). Supplement 2. List of primers used for the multiplex PCR-LDR-qPCR assay. Supplement 3. Genomic information for the breast cancer-specific CpG sites interrogated in the multiplex PCR, LDR, QPCR assay described in this report. Supplement 4. A. Statistical summary of the $\beta$ values (methylation level) for $3 \mathrm{CpG}$ markers across major types of cancer. $\beta$ value ranges from 0 (ummethylated) to 1 (completely methylated). $\mathrm{PT}=$ primary tumor; $\mathrm{SN}=$ solid normal. B-D. Statistical comparison (for each of the marker) between each subgroup. Supplement 5. Relationship between CpG methylation and Primary Tumor Stage. Supplement 6. Relationship between CpG methylation and molecular subtypes of breast cancer. Supplement 7. Relationship between CpG methylation and patient age. Supplement 8 .

Relationship between $\mathrm{CpG}$ methylation and patient race. Supplement 9 Relationship between CpG methylation and patient ethnicity. Supplement 10. Relationship between CpG methylation and gene expression.

\section{Abbreviations}

BrCa: Breast cancer; cfDNA: Cell-free DNA; ctDNA: Circulating tumor DNA; gDNA: Genomic DNA; LDR: Ligase detection reaction; PT: Primary tumor

\section{Acknowledgements}

The authors thank David Gelfand, Bill Efcavitch, Olivier Elemento, Bert Gold, Steve Lipkin, Cristian Ruiz Rueda, Chris Mason, Ken Offit, Pat Paty, Bernard Peperstraete, Mark Pochapin, and Eugene Spier for helpful discussions.

\section{Authors' contributions}

MDB is the primary writer, conducted data analysis, and contributed to conceptualization and design of the project. JW conducted the experiments and contributed to project design and manuscript writing. SFG contributed to manuscript writing. PBF contributed to experimental design and data analysis. AHM contributed to data analysis. AS contributed to conceptualization and design of the project. SAS contributed to conceptualization and design of the project. FB contributed to conceptualization and design of the project, as well as manuscript writing. All of the authors have read and approved the manuscript.

\section{Authors' information}

Not applicable.

\section{Funding}

This study was supported by the following: (i) Research Grant from Earlier. org, Friends for an Earlier Breast Cancer Test (MDB); (ii) Weill Cornell Medicine funding through distribution of royalties from intellectual property generated by the Barany laboratory; (iii) A Sponsored Research Agreement between AcuamarkDx and Weill Cornell Medicine; (iv) The Biotechnology Resource Center of Biomodular Multi Scale Systems CBM2 for Precision Molecular Diagnostics, NIH grant P41 EB020594; and (v) Research Grant from Laura Crandall Brown Foundation and The Foundation for Women's Cancer (SFG). All of the aforementioned funding bodies were not involved in the design of the study; collection, analysis, and interpretation of data; and writing of the manuscript.

\section{Availability of data and materials}

We did not generate new datasets for this article.

Ethics approval and consent to participate

The study did not involve human participation and is not subjected to ethical approval and consent.

\section{Consent for publication}

The study did not involve human participation and is not subjected to consent for publication.

\section{Competing interests}

MDB, AHM, JH, PBF, SFG and FB are shareholders in AcuamarkDx.

\section{Author details}

'Department of Microbiology and Immunology, Weill Cornell Medicine, New York, NY 10065, USA. 'Department of Surgery, Weill Cornell Medicine, New York, NY 10065, USA. ${ }^{3}$ Department of Mechanical Engineering, The University of Kansas, Lawrence, KS 66047, USA.

Received: 23 September 2019 Accepted: 23 January 2020 Published online: 31 January 2020

References

1. Siegel RL, Miller KD, Jemal A. Cancer statistics, 2019. CA Cancer J Clin. 2019; 69(1):7-34.

2. Bray F, Ferlay J, Soerjomataram I, Siegel RL, Torre LA, Jemal A. Global cancer statistics 2018: GLOBOCAN estimates of incidence and mortality worldwide for 36 cancers in 185 countries. CA Cancer J Clin. 2018;68(6):394-424.

3. Tang Q, Cheng J, Cao X, Surowy H, Burwinkel B. Blood-based DNA methylation as biomarker for breast cancer: a systematic review. Clin Epigenetics. 2016;8:115.

4. Antoniou A, Pharoah PD, Narod S, Risch HA, Eyfjord JE, Hopper JL, Loman N Olsson $\mathrm{H}$, Johannsson $\mathrm{O}$, Borg A, et al. Average risks of breast and ovarian cancer associated with BRCA1 or BRCA2 mutations detected in case series 
unselected for family history: a combined analysis of 22 studies. Am J Hum Genet. 2003;72(5):1117-30.

5. O'Shaughnessy J. Extending survival with chemotherapy in metastatic breast cancer. Oncologist. 2005;10(Suppl 3):20-9.

6. Welch HG, Prorok PC, O'Malley AJ, Kramer BS. Breast-Cancer tumor size, Overdiagnosis, and mammography screening effectiveness. N Engl J Med. 2016;375(15):1438-47.

7. Nelson HD, Pappas M, Cantor A, Griffin J, Daeges M, Humphrey L. Harms of Breast Cancer Screening: Systematic Review to Update the 2009 U.S. preventive services task force recommendation. Ann Intern Med. 2016; 164(4):256-67.

8. Loke SY, Lee ASG. The future of blood-based biomarkers for the early detection of breast cancer. Eur J Cancer. 2018:92:54-68.

9. Alimirzaie S, Bagherzadeh M, Akbari MR. Liquid biopsy in breast cancer: a comprehensive review. Clin Genet. 2019.

10. Rohanizadegan M. Analysis of circulating tumor DNA in breast cancer as a diagnostic and prognostic biomarker. Cancer Genet. 2018;228-229:159-68.

11. Buono G, Gerratana L, Bulfoni M, Provinciali N, Basile D, Giuliano M, Corvaja C, Arpino G, Del Mastro L, De Placido S, et al. Circulating tumor DNA analysis in breast cancer: is it ready for prime-time? Cancer Treat Rev. 2019;73:73-83

12. Kato S, Schwaederle MC, Fanta PT, Okamura R, Leichman L, Lippman SM, Lanman RB, Raymond VM, Talasaz A, Kurzrock R. Genomic assessment of blood-derived circulating tumor DNA in patients with colorectal cancers: correlation with tissue sequencing, therapeutic response, and survival. JCO Precis Oncol. 2019;3.

13. Zill OA, Banks KC, Fairclough SR, Mortimer SA, Vowles JV, Mokhtari R, Gandara DR, Mack PC, Odegaard JI, Nagy RJ, et al. The landscape of actionable genomic alterations in cell-free circulating tumor DNA from 21,807 advanced Cancer patients. Clin Cancer Res. 2018;24(15):3528-38.

14. Mansukhani S, Barber LJ, Kleftogiannis D, Moorcraft SY, Davidson M, Woolston A, Proszek PZ, Griffiths B, Fenwick K, Herman B, et al. Ultrasensitive mutation detection and genome-wide DNA copy number reconstruction by error-corrected circulating tumor DNA sequencing. Clin Chem. 2018;64(11):1626-35.

15. Kato S, Okamura R, Baumgartner JM, Patel H, Leichman L, Kelly K, Sicklick JK, Fanta PT, Lippman SM, Kurzrock R. Analysis of circulating tumor DNA and clinical correlates in patients with esophageal, Gastroesophageal junction, and gastric adenocarcinoma. Clin Cancer Res. 2018;24(24):6248-56.

16. Wyatt AW, Annala M, Aggarwal R, Beja K, Feng F, Youngren J, Foye A, Lloyd P, Nykter M, Beer TM, et al. Concordance of Circulating Tumor DNA and Matched Metastatic Tissue Biopsy in Prostate Cancer. J Natl Cancer Inst. 2017;109(12). https://doi.org/10.1093/jnci/djx118.

17. Hovelson DH, Liu CJ, Wang Y, Kang Q, Henderson J, Gursky A, Brockman S, Ramnath N, Krauss JC, Talpaz M, et al. Rapid, ultra low coverage copy number profiling of cell-free DNA as a precision oncology screening strategy. Oncotarget. 2017;8(52):89848-66.

18. Danese E, Minicozzi AM, Benati M, Montagnana M, Paviati E, Salvagno GL, Lima-Oliveira G, Gusella M, Pasini F, Lippi G, et al. Comparison of genetic and epigenetic alterations of primary tumors and matched plasma samples in patients with colorectal cancer. PLoS One. 2015;10(5):e0126417.

19. Lofton-Day C, Model F, Devos T, Tetzner R, Distler J, Schuster M, Song X Lesche R, Liebenberg $V$, Ebert $M$, et al. DNA methylation biomarkers for blood-based colorectal cancer screening. Clin Chem. 2008;54(2):414-23.

20. Weiss G, Schlegel A, Kottwitz D, Konig T, Tetzner R. Validation of the SHOX2/PTGER4 DNA methylation marker panel for plasma-based discrimination between patients with malignant and nonmalignant lung disease. J Thorac Oncol. 2017;12(1):77-84.

21. Pedersen SK, Symonds EL, Baker RT, Murray DH, McEvoy A, Van Doorn SC, Mundt MW, Cole SR, Gopalsamy G, Mangira D, et al. Evaluation of an assay for methylated BCAT1 and IKZF1 in plasma for detection of colorectal neoplasia. BMC Cancer. 2015;15:654.

22. Perlin $\mathrm{E}$, Moquin RB. Serum DNA levels in patients with malignant disease. Am J Clin Pathol. 1972;58(5):601-2.

23. Leon SA, Shapiro B, Sklaroff DM, Yaros MJ. Free DNA in the serum of cancer patients and the effect of therapy. Cancer Res. 1977;37(3):646-50.

24. Phallen J, Sausen M, Adleff V, Leal A, Hruban C, White J, Anagnostou V, Fiksel J, Cristiano S, Papp E, et al. Direct detection of early-stage cancers using circulating tumor DNA. Sci Transl Med. 2017;9(403). https://doi.org/10. 1126/scitranslmed.aan2415.

25. Kaiser J. National Institutes of Health. $\mathrm{NCl}$ gears up for cancer genome project. Science. 2005;307(5713):1182.
26. Zhu J, Sanborn JZ, Benz S, Szeto C, Hsu F, Kuhn RM, Karolchik D, Archie J, Lenburg ME, Esserman LJ, et al. The UCSC Cancer genomics browser. Nat Methods. 2009;6(4):239-40.

27. Goldman M, Craft B, Swatloski T, Ellrott K, Cline M, Diekhans M, Ma S, Wilks C, Stuart J, Haussler D, et al. The UCSC Cancer genomics browser: update 2013. Nucleic Acids Res. 2013;41(Database issue):D949-54.

28. Patch AM, Christie EL, Etemadmoghadam D, Garsed DW, George J, Fereday S, Nones K, Cowin P, Alsop K, Bailey PJ, et al. Whole-genome characterization of chemoresistant ovarian cancer. Nature. 2015;521(7553): 489-94.

29. Farkas SA, Milutin-Gasperov N, Grce M, Nilsson TK. Genome-wide DNA methylation assay reveals novel candidate biomarker genes in cervical cancer. Epigenetics. 2013;8(11):1213-25.

30. Killian JK, Dorssers LC, Trabert B, Gillis AJ, Cook MB, Wang Y, Waterfall JJ, Stevenson $\mathrm{H}$, Smith WI Jr, Noyes N, et al. Imprints and DPPA3 are bypassed during pluripotency- and differentiation-coupled methylation reprogramming in testicular germ cell tumors. Genome Res. 2016;26(11): 1490-504.

31. Vandiver AR, Irizarry RA, Hansen KD, Garza LA, Runarsson A, Li X, Chien AL, Wang TS, Leung SG, Kang S, et al. Age and sun exposure-related widespread genomic blocks of hypomethylation in nonmalignant skin. Genome Biol. 2015;16:80.

32. Horvath S, Mah V, Lu AT, Woo JS, Choi OW, Jasinska AJ, Riancho JA, Tung S, Coles NS, Braun J, et al. The cerebellum ages slowly according to the epigenetic clock. Aging (Albany NY). 2015;7(5):294-306.

33. Liu Y, Aryee MJ, Padyukov L, Fallin MD, Hesselberg E, Runarsson A, Reinius L, Acevedo N, Taub M, Ronninger M, et al. Epigenome-wide association data implicate DNA methylation as an intermediary of genetic risk in rheumatoid arthritis. Nat Biotechnol. 2013;31(2):142-7.

34. Absher DM, Li X, Waite LL, Gibson A, Roberts K, Edberg J, Chatham WW, Kimberly RP. Genome-wide DNA methylation analysis of systemic lupus erythematosus reveals persistent hypomethylation of interferon genes and compositional changes to CD4+ T-cell populations. PLoS Genet. 2013;9(8): e1003678.

35. Li H, Chiappinelli KB, Guzzetta AA, Easwaran H, Yen RW, Vatapalli R, Topper MJ, Luo J, Connolly RM, Azad NS, et al. Immune regulation by low doses of the DNA methyltransferase inhibitor 5-azacitidine in common human epithelial cancers. Oncotarget. 2014;5(3):587-98.

36. Iorio F, Knijnenburg TA, Vis DJ, Bignell GR, Menden MP, Schubert M, Aben N, Goncalves E, Barthorpe S, Lightfoot $\mathrm{H}$, et al. A landscape of Pharmacogenomic interactions in Cancer. Cell. 2016;166(3):740-54.

37. Coyle KM, Murphy JP, Vidovic D, Vaghar-Kashani A, Dean CA, Sultan M, Clements D, Wallace M, Thomas ML, Hundert A, et al. Breast cancer subtype dictates DNA methylation and ALDH1A3-mediated expression of tumor suppressor RARRES1. Oncotarget. 2016;7(28):44096-112.

38. Kent WJ, Sugnet CW, Furey TS, Roskin KM, Pringle TH, Zahler AM, Haussler D. The human genome browser at UCSC. Genome Res. 2002; 12(6):996-1006

39. Subramanian A, Tamayo P, Mootha VK, Mukherjee S, Ebert BL, Gillette MA, Paulovich A, Pomeroy SL, Golub TR, Lander ES, et al. Gene set enrichment analysis: a knowledge-based approach for interpreting genome-wide expression profiles. Proc Natl Acad Sci U S A. 2005;102(43):15545-50.

40. Williamson EA, Wolf I, O'Kelly J, Bose S, Tanosaki S, Koeffler HP. BRCA1 and FOXA1 proteins coregulate the expression of the cell cycle-dependent kinase inhibitor p27(Kip1). Oncogene. 2006;25(9):1391-9.

41. Nakshatri H, Badve S. FOXA1 in breast cancer. Expert Rev Mol Med. 2009;11:e8.

42. Turcotte S, Forget MA, Beauseigle D, Nassif E, Lapointe R. Prostate-derived Ets transcription factor overexpression is associated with nodal metastasis and hormone receptor positivity in invasive breast cancer. Neoplasia. 2007; 9(10):788-96.

43. Holbro T, Beerli RR, Maurer F, Koziczak M, Barbas CF 3rd, Hynes NE. The ErbB2/ErbB3 heterodimer functions as an oncogenic unit: ErbB2 requires ErbB3 to drive breast tumor cell proliferation. Proc Natl Acad Sci U S A. 2003;100(15):8933-8.

44. Eeckhoute J, Keeton EK, Lupien M, Krum SA, Carroll JS, Brown M. Positive cross-regulatory loop ties GATA-3 to estrogen receptor alpha expression in breast cancer. Cancer Res. 2007:67(13):6477-83.

45. Guillamot M, Manchado E, Chiesa M, Gomez-Lopez G, Pisano DG, Sacristan MP, Malumbres M. Cdc14b regulates mammalian RNA polymerase II and represses cell cycle transcription. Sci Rep. 2011;1:189. 
46. Lo TL, Yusoff P, Fong CW, Guo K, McCaw BJ, Phillips WA, Yang H, Wong ES, Leong HF, Zeng Q, et al. The ras/mitogen-activated protein kinase pathway inhibitor and likely tumor suppressor proteins, sprouty 1 and sprouty 2 are deregulated in breast cancer. Cancer Res. 2004;64(17):6127-36.

47. Cheng JC, Chang HM, Xiong S, So WK, Leung PC. Sprouty2 inhibits amphiregulin-induced down-regulation of E-cadherin and cell invasion in human ovarian cancer cells. Oncotarget. 2016;7(49):81645-60.

48. Joshi-Tope G, Gillespie M, Vastrik I, D'Eustachio P, Schmidt E, de Bono B, Jassal B, Gopinath GR, Wu GR, Matthews L, et al. Reactome: a knowledgebase of biological pathways. Nucleic Acids Res. 2005;33(Database issue):D428-32.

49. Rossetti S, Ren M, Visconti N, Corlazzoli F, Gagliostro V, Somenzi G, Yao J, Sun Y, Sacchi N. Tracing anti-cancer and cancer-promoting actions of alltrans retinoic acid in breast cancer to a RARalpha epigenetic mechanism of mammary epithelial cell fate. Oncotarget. 2016;7(52):87064-80.

50. Ribeiro MP, Santos AE, Custodio JB. Interplay between estrogen and retinoid signaling in breast cancer--current and future perspectives. Cancer Lett. 2014;353(1):17-24.

51. Tang $X H$, Gudas LJ. Retinoids, retinoic acid receptors, and cancer. Annu Rev Pathol. 2011;6:345-64.

52. O'Brien KM, Sandler DP, Xu Z, Kinyamu HK, Taylor JA, Weinberg CR. Vitamin D, DNA methylation, and breast cancer. Breast Cancer Res. 2018;20(1):70.

53. Cheng $H$, Qin $Y$, Fan $H$, Su P, Zhang X, Zhang H, Zhou G. Overexpression of CARM1 in breast cancer is correlated with poorly characterized clinicopathologic parameters and molecular subtypes. Diagn Pathol. 2013;8: 129.

54. Habashy HO, Rakha EA, Ellis IO, Powe DG. The oestrogen receptor coactivator CARM1 has an oncogenic effect and is associated with poor prognosis in breast cancer. Breast Cancer Res Treat. 2013;140(2):307-16.

55. Longo MC, Berninger MS, Hartley JL. Use of uracil DNA glycosylase to control carry-over contamination in polymerase chain reactions. Gene. 1990; 93(1):125-8.

56. Salvi S, Gurioli G, De Giorgi U, Conteduca V, Tedaldi G, Calistri D, Casadio V. Cell-free DNA as a diagnostic marker for cancer: current insights. OncoTargets Ther. 2016;9:6549-59.

57. Huang CC, Du M, Wang L. Bioinformatics Analysis for Circulating Cell-Free DNA in Cancer. Cancers (Basel). 2019;11(6). https://doi.org/10.3390/ cancers 11060805.

58. Moss J, Magenheim J, Neiman D, Zemmour H, Loyfer N, Korach A, Samet Y, Maoz M, Druid H, Arner P, et al. Comprehensive human cell-type methylation atlas reveals origins of circulating cell-free DNA in health and disease. Nat Commun. 2018:9(1):5068

59. Liu X, Ren J, Luo N, Guo H, Zheng Y, Li J, Tang F, Wen L, Peng J. Comprehensive DNA methylation analysis of tissue of origin of plasma cellfree DNA by methylated CPG tandem amplification and sequencing (MCTASeq). Clin Epigenetics. 2019;11(1):93

60. Kidess E, Jeffrey SS. Circulating tumor cells versus tumor-derived cell-free DNA: rivals or partners in cancer care in the era of single-cell analysis? Genome Med. 2013;5(8):70.

61. Issa JP. DNA methylation as a therapeutic target in cancer. Clin Cancer Res. 2007;13(6):1634-7.

62. Visvanathan K, Fackler MS, Zhang Z, Lopez-Bujanda ZA, Jeter SC, Sokoll LJ, Garrett-Mayer E, Cope LM, Umbricht CB, Euhus DM, et al. Monitoring of serum DNA methylation as an early independent marker of response and survival in metastatic breast Cancer: TBCRC 005 prospective biomarker study. J Clin Oncol. 2017;35(7):751-8.

63. Takahashi H, Kagara N, Tanei T, Naoi Y, Shimoda M, Shimomura A, Shimazu K, Kim SJ, Noguchi S. Correlation of methylated circulating tumor DNA with response to Neoadjuvant chemotherapy in breast Cancer patients. Clin Breast Cancer. 2017;17(1):61-9 e63.

64. Shan M, Yin H, Li J, Li X, Wang D, Su Y, Niu M, Zhong Z, Wang J, Zhang X, et al. Detection of aberrant methylation of a six-gene panel in serum DNA for diagnosis of breast cancer. Oncotarget. 2016;7(14):18485-94.

65. Fackler MJ, Lopez Bujanda Z, Umbricht C, Teo WW, Cho S, Zhang Z, Visvanathan K, Jeter S, Argani P, Wang C, et al. Novel methylated biomarkers and a robust assay to detect circulating tumor DNA in metastatic breast cancer. Cancer Res. 2014;74(8):2160-70.

66. Kloten V, Becker B, Winner K, Schrauder MG, Fasching PA, Anzeneder T, Veeck J, Hartmann A, Knuchel R, Dahl E. Promoter hypermethylation of the tumor-suppressor genes ITIH5, DKK3, and RASSF1A as novel biomarkers for blood-based breast cancer screening. Breast Cancer Res. 2013;15(1):R4
67. Agostini M, Enzo MV, Bedin C, Belardinelli V, Goldin E, Del Bianco P, Maschietto E, D'Angelo E, Izzi L, Saccani A, et al. Circulating cell-free DNA: a promising marker of regional lymphonode metastasis in breast cancer patients. Cancer Biomark. 2012;11(2-3):89-98.

68. Brooks JD, Cairns P, Shore RE, Klein CB, Wirgin I, Afanasyeva Y, ZeleniuchJacquotte A. DNA methylation in pre-diagnostic serum samples of breast cancer cases: results of a nested case-control study. Cancer Epidemiol. 2010; 34(6):717-23.

69. Shukla S, Mirza S, Sharma G, Parshad R, Gupta SD, Ralhan R. Detection of RASSF1A and RARbeta hypermethylation in serum DNA from breast cancer patients. Epigenetics. 2006;1(2):88-93.

70. Bianco S, Jangal M, Garneau D, Gevry N. LRH-1 controls proliferation in breast tumor cells by regulating CDKN1A gene expression. Oncogene. 2015; 34(34):4509-18.

71. Chand AL, Wijayakumara DD, Knower KC, Herridge KA, Howard TL, Lazarus $K A$, Clyne CD. The orphan nuclear receptor $L R H-1$ and ERalpha activate GREB1 expression to induce breast cancer cell proliferation. PLoS One. 2012; 7(2):e31593.

72. Wang $S$, Zou Z, Luo X, Mi Y, Chang H, Xing D. LRH1 enhances cell resistance to chemotherapy by transcriptionally activating MDC1 expression and attenuating DNA damage in human breast cancer. Oncogene. 2018; 37(24):3243-59

73. Pang JB, Molania R, Chand A, Knower K, Takano EA, Byrne DJ, Mikeska T, Millar EKA, Lee CS, O'Toole SA, et al. LRH-1 expression patterns in breast cancer tissues are associated with tumour aggressiveness. Oncotarget. 2017; 8(48):83626-36.

74. Bianco S, Brunelle M, Jangal M, Magnani L, Gevry N. LRH-1 governs vital transcriptional programs in endocrine-sensitive and -resistant breast cancer cells. Cancer Res. 2014;74(7):2015-25.

75. Wallace JA, Pitarresi JR, Sharma N, Palettas M, Cuitino MC, Sizemore ST, Yu L, Sanderlin A, Rosol TJ, Mehta KD, et al. Protein kinase C Beta in the tumor microenvironment promotes mammary tumorigenesis. Front Oncol. 2014;4: 87.

76. Li H, Weinstein IB. Protein kinase $\mathrm{C}$ beta enhances growth and expression of cyclin D1 in human breast cancer cells. Cancer Res. 2006;66(23):11399-408.

77. Sledge GW Jr, Gokmen-Polar Y. Protein kinase C-beta as a therapeutic target in breast cancer. Semin Oncol. 2006;33(3 Suppl 9):S15-8.

78. Grossoni VC, Todaro LB, Kazanietz MG, de Kier Joffe ED, Urtreger AJ. Opposite effects of protein kinase C beta1 (PKCbeta1) and PKCepsilon in the metastatic potential of a breast cancer murine model. Breast Cancer Res Treat. 2009;118(3):469-80.

79. Gomez-Maldonado L, Tiana M, Roche O, Prado-Cabrero A, Jensen L, Fernandez-Barral A, Guijarro-Munoz I, Favaro E, Moreno-Bueno G, Sanz L, et al. EFNA3 long noncoding RNAs induced by hypoxia promote metastatic dissemination. Oncogene. 2015;34(20):2609-20.

80. Gong W, Qie S, Huang P, Xi J. Deletion of long noncoding RNA EFNA3 aggravates hypoxia-induced injury in PC-12 cells by upregulation of miR101a. J Cell Biochem. 2019;120(1):836-47.

81. Swierczynski S, Klieser E, Illig R, Alinger-Scharinger B, Kiesslich T, Neureiter D. Histone deacetylation meets miRNA: epigenetics and post-transcriptional regulation in cancer and chronic diseases. Expert Opin Biol Ther. 2015;15(5): 651-64.

82. Wang $\mathrm{S}, \mathrm{Wu}$ W, Claret FX. Mutual regulation of microRNAs and DNA methylation in human cancers. Epigenetics. 2017;12(3):187-97.

83. Haimovich G, Medina DA, Causse SZ, Garber M, Millan-Zambrano G, Barkai O, Chavez S, Perez-Ortin JE, Darzacq X, Choder M. Gene expression is circular: factors for mRNA degradation also foster mRNA synthesis. Cell. 2013;153(5):1000-11.

84. Panagopoulou M, Karaglani M, Balgkouranidou I, Biziota E, Koukaki T, Karamitrousis E, Nena E, Tsamardinos I, Kolios G, Lianidou E, et al. Circulating cell-free DNA in breast cancer: size profiling, levels, and methylation patterns lead to prognostic and predictive classifiers. Oncogene. 2019; 38(18):3387-401.

85. Mishima C, Kagara N, Matsui S, Tanei T, Naoi Y, Shimoda M, Shimomura A Shimazu K, Kim SJ, Noguchi S. Promoter methylation of TRIM9 as a marker for detection of circulating tumor DNA in breast cancer patients. Springerplus. 2015;4:635.

86. Parisi C, Mastoraki S, Markou A, Strati A, Chimonidou M, Georgoulias V, Lianidou ES. Development and validation of a multiplex methylation specific PCR-coupled liquid bead array for liquid biopsy analysis. Clin Chim Acta. 2016:461:156-64 
87. Fu D, Ren C, Tan H, Wei J, Zhu Y, He C, Shao W, Zhang J. Sox17 promoter methylation in plasma DNA is associated with poor survival and can be used as a prognostic factor in breast cancer. Medicine. 2015;94(11):e637.

88. Mastoraki S, Strati A, Tzanikou E, Chimonidou M, Politaki E, Voutsina A, Psyrri A, Georgoulias V, Lianidou E. ESR1 methylation: a liquid biopsy-based epigenetic assay for the follow-up of patients with metastatic breast Cancer receiving endocrine treatment. Clin Cancer Res. 2018;24(6):1500-10.

89. Chimonidou M, Strati A, Malamos N, Georgoulias V, Lianidou ES. SOX17 promoter methylation in circulating tumor cells and matched cell-free DNA isolated from plasma of patients with breast cancer. Clin Chem. 2013;59(1): 270-9.

90. Bosviel R, Garcia S, Lavediaux G, Michard E, Dravers M, Kwiatkowski F, Bignon YJ, Bernard-Gallon DJ. BRCA1 promoter methylation in peripheral blood DNA was identified in sporadic breast cancer and controls. Cancer Epidemiol. 2012:36(3):e177-82.

91. Sharma G, Mirza S, Prasad CP, Srivastava A, Gupta SD, Ralhan R. Promoter hypermethylation of p16INK4A, p14ARF, CyclinD2 and Slit2 in serum and tumor DNA from breast cancer patients. Life Sci. 2007;80(20):1873-81.

92. Martinez-Galan J, Torres B, Del Moral R, Munoz-Gamez JA, Martin-Oliva D, Villalobos M, Nunez MI, Luna Jde D, Oliver FJ, Ruiz de Almodovar JM. Quantitative detection of methylated ESR1 and 14-3-3-sigma gene promoters in serum as candidate biomarkers for diagnosis of breast cancer and evaluation of treatment efficacy. Cancer Biol Ther. 2008;7(6):958-65.

93. Grunau C, Clark SJ, Rosenthal A. Bisulfite genomic sequencing: systematic investigation of critical experimental parameters. Nucleic Acids Res. 2001; 29(13):E65.

94. Lee KH, Shin TJ, Kim WH, Lee SY, Cho JY. Methylation of LINE-1 in cell-free DNA serves as a liquid biopsy biomarker for human breast cancers and dog mammary tumors. Sci Rep. 2019;9(1):175.

95. Kristiansen S, Nielsen D, Soletormos G. Detection and monitoring of hypermethylated RASSF1A in serum from patients with metastatic breast cancer. Clin Epigenetics. 2016;8:35.

96. Ng EK, Leung CP, Shin VY, Wong CL, Ma ES, Jin HC, Chu KM, Kwong A. Quantitative analysis and diagnostic significance of methylated SLC19A3 DNA in the plasma of breast and gastric cancer patients. PLoS One. 2011; 6(7):e22233.

97. Shen SY, Singhania R, Fehringer G, Chakravarthy A, Roehrl MHA, Chadwick D, Zuzarte PC, Borgida A, Wang TT, Li T, et al. Sensitive tumour detection and classification using plasma cell-free DNA methylomes. Nature. 2018; 563(7732):579-83.

98. Maggi EC, Gravina S, Cheng H, Piperdi B, Yuan Z, Dong X, Libutti SK, Vijg J, Montagna C. Development of a method to implement whole-genome bisulfite sequencing of cfDNA from Cancer patients and a mouse tumor Model. Front Genet. 2018;9:6.

99. Liu L, Toung JM, Jassowicz AF, Vijayaraghavan R, Kang H, Zhang R, Kruglyak KM, Huang HJ, Hinoue T, Shen $\mathrm{H}$, et al. Targeted methylation sequencing of plasma cell-free DNA for cancer detection and classification. Ann Oncol. 2018;29(6):1445-53.

100. Holmila R, Sklias A, Muller DC, Degli Esposti D, Guilloreau P, McKay J, Sangrajrang S, Srivatanakul P, Hainaut P, Merle P, et al. Targeted deep sequencing of plasma circulating cell-free DNA reveals Vimentin and Fibulin 1 as potential epigenetic biomarkers for hepatocellular carcinoma. PLOS One. 2017;12(3):e0174265.

101. Vaca-Paniagua F, Oliver J, Nogueira da Costa a, Merle P, McKay J, Herceg Z, Holmila R. Targeted deep DNA methylation analysis of circulating cell-free DNA in plasma using massively parallel semiconductor sequencing. Epigenomics. 2015;7(3):353-62

102. Sun K, Jiang P, Chan KC, Wong J, Cheng YK, Liang RH, Chan WK, Ma ES, Chan $\mathrm{SL}$, Cheng SH, et al. Plasma DNA tissue mapping by genome-wide methylation sequencing for noninvasive prenatal, cancer, and transplantation assessments. Proc Natl Acad Sci U S A. 2015;112(40):E5503-12.

103. Lissa D, Robles Al. Methylation analyses in liquid biopsy. Transl Lung Cancer Res. 2016;5(5):492-504

\section{Publisher's Note}

Springer Nature remains neutral with regard to jurisdictional claims in published maps and institutional affiliations.

Ready to submit your research? Choose BMC and benefit from:

- fast, convenient online submission

- thorough peer review by experienced researchers in your field

- rapid publication on acceptance

- support for research data, including large and complex data types

- gold Open Access which fosters wider collaboration and increased citations

- maximum visibility for your research: over $100 \mathrm{M}$ website views per year

At BMC, research is always in progress.

Learn more biomedcentral.com/submissions 